University of Louisville

ThinkIR: The University of Louisville's Institutional Repository

Electronic Theses and Dissertations

$5-2012$

\title{
Prison wardens' perceptions of sex offenders, sex offender registration, community notification, and residency restrictions.
}

David Patrick Connor

University of Louisville

Follow this and additional works at: https://ir.library.louisville.edu/etd

\section{Recommended Citation}

Connor, David Patrick, "Prison wardens' perceptions of sex offenders, sex offender registration, community notification, and residency restrictions." (2012). Electronic Theses and Dissertations. Paper 270.

https://doi.org/10.18297/etd/270

This Master's Thesis is brought to you for free and open access by ThinkIR: The University of Louisville's Institutional Repository. It has been accepted for inclusion in Electronic Theses and Dissertations by an authorized administrator of ThinkIR: The University of Louisville's Institutional Repository. This title appears here courtesy of the author, who has retained all other copyrights. For more information, please contact thinkir@louisville.edu. 


\title{
PRISON WARDENS' PERCEPTIONS OF SEX OFFENDERS, SEX OFFENDER REGISTRATION, COMMUNITY NOTIFICATION, AND RESIDENCY RESTRICTIONS
}

\section{By}

\author{
David Patrick Connor \\ B.A., Northern Kentucky University, 2009
}

\begin{abstract}
A Thesis
Submitted to the Faculty of the

College of Arts and Sciences of the University of Louisville in Partial Fulfillment of the Requirements

for the Degree of

Master of Science

Department of Justice Administration

University of Louisville

Louisville, Kentucky
\end{abstract}

May 2012 
Copyright 2012 by David Patrick Connor All rights reserved 
PRISON WARDENS' PERCEPTIONS OF SEX OFFENDERS, SEX OFFENDER REGISTRATION, COMMUNITY NOTIFICATION, AND RESIDENCY RESTRICTIONS

\section{By}

David Patrick Connor

B.A., Northern Kentucky University, 2009

A Thesis Approved on

April 17, 2012

by the following Thesis Committee:

Dr. Richard Tewksbury

Thesis Director

Dr. Deborah Keeling

Dr. Elizabeth Mustaine 


\section{ACKNOWLEDGEMENTS}

I would like to acknowledge my Thesis Director and mentor, Dr. Richard Tewksbury, for his assistance and support throughout my graduate school experience. $\mathrm{He}$ has afforded me with endless opportunities to overcome obstacles and prosper in the face of adversity. I would also like to thank Dr. Deborah Keeling and Dr. Elizabeth Mustaine, both members of my thesis committee, for their willingness to endorse this project.

Further, my graduate student colleagues, especially Amanda Denton, deserve recognition for their comments and suggestions. Lastly, I would like to recognize my parents and siblings for their unyielding encouragement and love. 


\begin{abstract}
PRISON WARDENS' PERCEPTIONS OF SEX OFFENDERS, SEX OFFENDER REGISTRATION, COMMUNITY NOTIFICATION, AND RESIDENCY RESTRICTIONS

David Patrick Connor
\end{abstract}

April 17, 2012

There is relatively little known about how criminal justice system actors perceive sex offenders and the fairness, efficacy, and scope of policies aimed at sex offenders. Similarly, there is sparse research that specifically examines the attitudes, beliefs, and experiences of prison wardens. Following in the footsteps of earlier research (Tewksbury \& Mustaine, 2011; Tewksbury, Mustaine, \& Payne, 2011, in press), the present study addresses these gaps by considering the attitudes and beliefs toward sex offenders held by wardens. This examination includes perceptions about sex offenders as prison inmates, sex offender registration, community notification, and residency restrictions. Further, this research assesses the utility of the 18-item Community Attitudes Toward Sex Offenders (CATSO) scale (Church, Wakeman, Miller, Clements, \& Sun, 2008), which was advocated for use with criminal justice system actors, to determine whether or not the instrument can be effectively utilized with wardens. Findings and policy implications are discussed. 


\section{TABLE OF CONTENTS}

\section{PAGE}

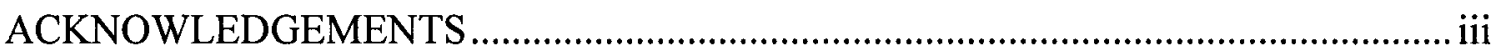

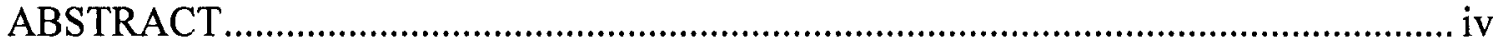

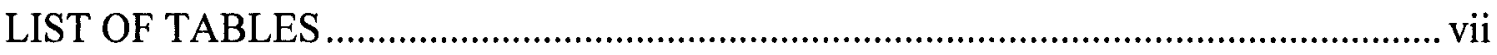

INTRODUCTION

Perceptions of the General Public...................................................................... 5

Perceptions of Sex Offenders............................................................................ 13

Perceptions of Criminal Justice System Actors ..................................................... 20

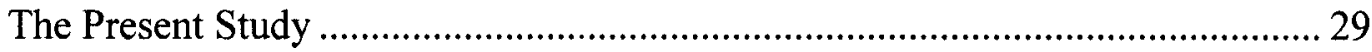

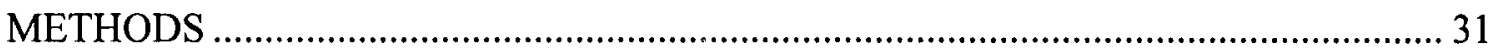

Sample

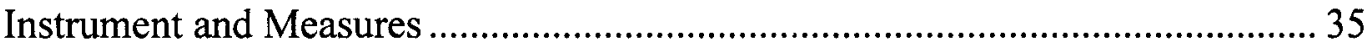

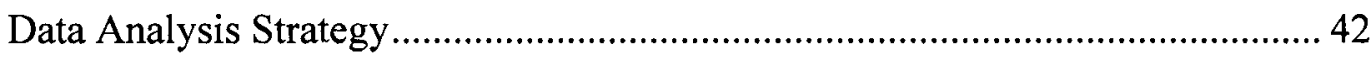

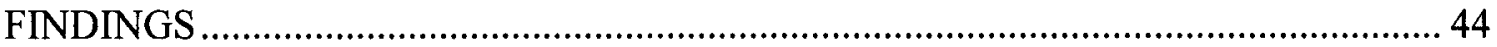

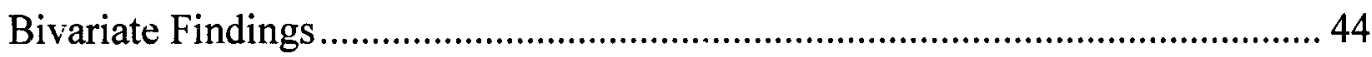


Multivariate Findings........................................................................................ 56

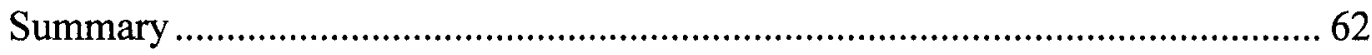

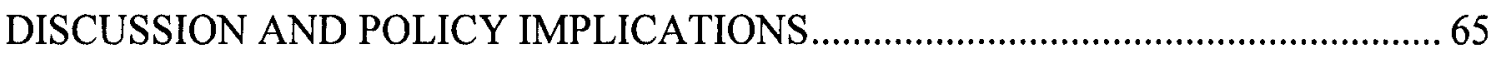

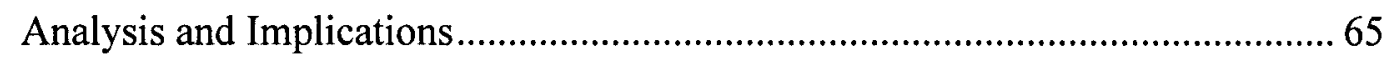

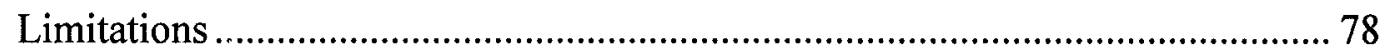

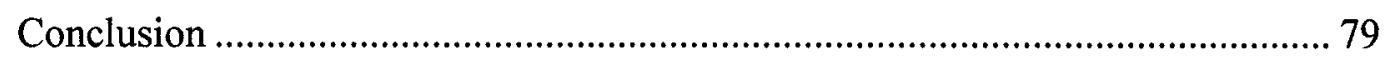

REFERENCES …

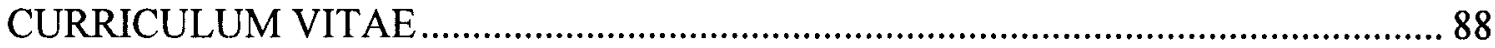




\section{LIST OF TABLES}

TABLE

PAGE

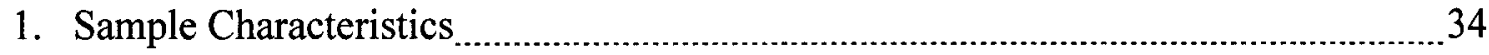

2. Sex Offenders as Prison Inmates

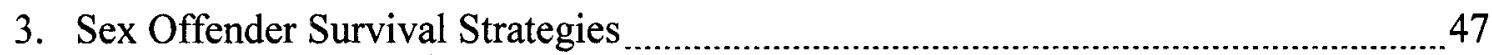

4. Institutional Sex Offender Treatment Programs

5. SORN and Residency Restrictions

6. How to Best Conduct Community Notification

7. What Should Be Reported on a Registrant's Sex Offender Registry Page ................. 51

8. Restricting Sex Offenders from Popular Child Congregation Locations ....................52

9. 18 CATSO Items

10. Five-Component Factor Analysis of CATSO Survey Items ….................................58

11. Influences on Views of the Fairness of Community Notification Laws _.................60

12. Influences on Views of the Effectiveness of Community Notification Laws ............61

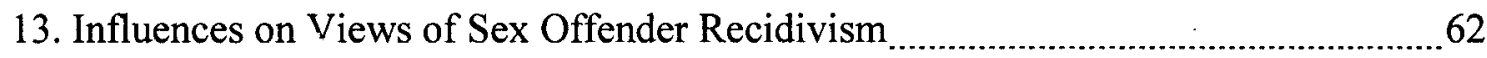




\section{CHAPTER I}

\section{INTRODUCTION}

No matter the population, sex offenders often evoke strong feelings. Society, as a whole, has consistently looked upon such offenders with disgust and disdain (Quinn, Forsyth, \& Mullen-Quinn, 2004). Perhaps this explains why, over the past several years, individuals convicted of sex offenses have been subjected to increasingly severe sanctions. In particular, efforts have been made to increase the supervision of these criminals and decrease their opportunities to further perpetrate crimes. Without a doubt, many emerging laws and criminal justice policies have targeted sex offenders, especially those convicted of victimizing children. In addition to progressively long incarcerations, sex offenders potentially face registration and community notification, residency restrictions, and other restrictive criminal justice policies.

Spotlighting society's harsh treatment of sex offenders, one of the most recent developments has been the creation of sex offender registries. Although it is not a new concept, criminal registration is experiencing a revival (Logan, 2009). Sex offender registries are utilized in every jurisdiction in the United States, and these repositories of information provide online access to a wide array of facts about convicted sex offenders and their sex offenses (Tewksbury \& Higgins, 2005). Individuals convicted of sex offenses are typically required to provide local law enforcement and corrections authorities with name, photograph, address, birth date, Social Security number, fingerprints, offense history, date of convictions, and other information. In addition, sex 
offenders must verify the accuracy of this information on a routine basis for the duration of their registration, which may range from ten years to life.

Most arguments supporting sex offender registries emphasize public safety, particularly the protection of children. Proponents also contend that registration will permit law enforcement officials to quickly and easily ascertain the locations of sex offenders in their communities, facilitating sex crime investigations. Because Internet databases reveal the identification of sex offenders to the community, it is further maintained that sex offender registries reduce opportunities for recidivism. Despite evidence suggesting little or no effect of registration and community notification on recidivism rates (e.g., Adkins, Huff, \& Stageberg, 2000; Schram \& Milloy, 1995; Tewksbury \& Jennings, 2010; Zgoba, Witt, Dalessandro, \& Veysey, 2008), there remains general public approval concerning sex offender registries and a belief that most sex offenders will reoffend (e.g., Levenson, Brannon, Fortney, \& Baker, 2007; Zevitz, 2006).

The Jacob Wetterling Act (1994) was the first federal law that mandated registration of sex offenders in state-wide databases. As a result of Wetterling and subsequent legislation, each state now has a mandatory registration law that obligates sex offenders to provide their information to law enforcement officials and have this information provided to the public, most often through publicly available, Internet-based registries. However, it was Megan's Law (1996) in New Jersey that created sex offender registration and notification (SORN) legislation that was ultimately replicated nationwide. Culpable for transforming sex offender registries into publicly available online domains, the federal version of this statute (Public Law 104-145) requires state police agencies to make public information about sex offenders. 
Many states that use community notification have a three-tiered system based on the purported dangerousness of sex offenders that determines the degree of notification that will take place. When sex offenders are categorized as the lowest risk to public safety, notification is typically reserved for law enforcement officials only. Schools, daycares, and other neighborhood organizations are notified of the presence of sex offenders posing a medium risk to public safety. Those sex offenders considered the most dangerous, designated at high risk, will generate the most widespread notification, as the general public is notified. However, some jurisdictions subject all convicted sex offenders to community notification.

In 2000, the Campus Sex Crime Prevention Act further amended the original Wetterling Act, requiring registered sex offenders studying and working at colleges and universities to provide notice of their status as sex offenders to these institutions of higher learning. College and university officials are required to inform the campus community where information regarding registered sex offenders may be obtained. In fact, many colleges and universities consequently maintain their own distinctive online sex offender registries (Tewksbury \& Lees, 2006a). Exposing convicted sex offenders to further public scrutiny, a nationwide databank of registered sex offenders was created in 2005. The Dru Sjodin National Sex Offender Public Registry, as it was named in 2006, was designed by the Department of Justice to provide more efficient access to individual state sex offender registries.

Most recently, the Adam Walsh Act, signed into law in 2006, attempts to make the archiving and monitoring of sex offenders more efficient by creating a comprehensive and national system for sex offender registration. One of the most significant provisions 
of this act is that it specifies national standards for all sex offenders regardless of their home jurisdiction, including the requirement of DNA samples from all registrants. Like the earlier federal statutes concerning the public disclosure of sex offenders, all jurisdictions must comply with the provisions of the Walsh Act or face reduced federal grant funding.

Well over one-half of all states and numerous municipalities have sex offender residency restriction laws. Residency restriction laws often feature nebulous language to restrict registered sex offenders from living near locations described as "child congregation" areas. Such places are typically defined to include schools, parks, playgrounds, daycare centers, bus stops, and recreational facilities. Fluctuating between 500 feet and 2,500 feet, residency restriction laws assert that specific distances must be preserved between a sex offender's residence and various landmarks in the community.

The United States criminal justice system has held a leading position with implementing and enforcing sex offender registration, community notification, and residency restrictions aimed at preventing future sex crimes. However, there is little known about how criminal justice system actors perceive the fairness, efficacy, and scope of such sex offender laws (however, see Tewksbury \& Mustaine, 2011; Tewksbury et al., 2011 , in press). The purpose of this study, then, is to advance the understanding of how one group of criminal justice system actors - prison wardens - understand, perceive, and respond to the management of sex offenders. To do this, the proposed research will examine the perceptions of prison wardens concerning sex offenders, while focusing on observations of sex offenders both as prison inmates and registrants in the community. 
The study will demonstrate attitudes and beliefs held by wardens, shedding light on perceptions of sex offenders and sex offender policies.

\section{Perceptions of the General Public}

Before exploring prison wardens' perceptions, it is important to understand the public's attitudes and beliefs about sex offenders and sex offender policies. Because wardens are members of the collective public, perceptions held by community members may provide a foundation for likely attitudes and beliefs among wardens. The available literature on the topic of public perceptions about sex offenders and sex offender policies indicates that the general public largely endorses legal sanctions aimed at convicted sex offenders.

\section{Support for Sex Offender Policies}

Members of the general public largely support a variety of criminal justice policies aimed at convicted sex offenders, and they often endorse punitive measures to control sex offenders in the community. Comartin, Kernsmith, and Kernsmith (2009) used telephone surveys of 703 Michigan residents, and they found that respondents expressed support for numerous sex offender policies. Employment restrictions limiting sex offenders from working at schools and daycares (95\%) and other child congregation locations (91\%) showed the greatest support among community members. Respondents also expressed high levels of support for restricting sex offenders from living close to schools and daycares (88\%) and other child congregation locations (83\%). In terms of sex offender community notification, most believed it should be conducted by directly notifying neighbors $(85 \%)$ and online registration $(83 \%)$, while less than one-half felt it should be conducted in the newspaper (42\%). In terms of sex offender community 
supervision, most ( $83 \%)$ believed that sex offenders should wear electronic monitoring devices, and about one-half ( $48 \%$ ) felt that sex offenders should have a nighttime curfew. About one-half (49\%) also believed sex offenders should be sentenced to life in prison, and a significant minority (40\%) felt sex offenders should undergo castration.

Surveying 194 Florida residents, Levenson et al. (2007) also found that most members of the general public support a wide array of sex offender policies. Overall, they found that residents supported sex offender registration and community notification. Only $3 \%$ believed that no information about sex offenders should be made publicly available. More than three-quarters believed all sex offenders should be subject to community notification. In addition, community notification (83\%) and residency restrictions (58\%) were viewed by residents as effective strategies to reduce sex offenses, and about $73 \%$ indicated that they would support such sex offender policies even without scientific evidence of their effectiveness in preventing sexual victimization.

Such endorsement of punitive criminal justice policies, especially without scientific evidence, is likely the result of intense fear reported by members of the general public. Fear of sex offenders appears to be so pervasive among the public that they are willing to subject all individuals convicted of sex offenses to castigating criminal justice policies. In Kernsmith, Craun, and Foster's study (2009), 733 Michigan residents were asked questions about their fear of sex offenders and whether or not they agreed with sex offender registration focused on specific types of sex offenders. Most residents reported that they were afraid of pedophiles (80\%), incest offenders (78\%), and juvenile sex offenders $(70 \%)$. A majority reported that they were afraid of date rape offenders $(66 \%)$, 
sex offenders with a sex offense that was ten years old (62\%), and spousal rapists $(59 \%)$. A significant minority (45\%) reported that they were fearful of statutory rapists.

All types of sex offenders, pedophiles (97\%), incest offenders (96\%), juvenile sex offenders $(86 \%)$, date rape offenders $(84 \%)$, sex offenders with a sex offense more than ten years old (86\%), spousal rapists (71\%), and statutory rapists $(65 \%)$, were seen by a majority of residents as appropriately subject to sex offender registration. This is consistent with Schiavone and Jeglic's study (2009), where a majority of the public reported that nearly all sex offenders should be subject to sex offender registration. After surveying 115 community members from 15 different states, they found that high risk sex offenders $(89 \%)$, moderate risk sex offenders $(82 \%)$, and low risk sex offenders were seen as appropriately subject to sex offender registration.

It is clear that the public fears all sex offenders, especially those with child victims, and expresses the most desire for such offenders to become subject to criminal registration. With this in mind, it is important to note that members of the general public, who already largely support sex offender policies, may be more likely to endorse these policies if they have children. In fact, those with more children are more likely to see criminal justice policies aimed at sex offenders as appropriate restrictions.

Using data from a telephone survey with 1,308 Florida residents, Mancini, Shields, Mears, and Beaver (2010) found that residents with children were significantly more likely than residents without children to endorse sex offender residency restrictions. The odds of residents with children supporting these laws rather than not supporting them were $58 \%$ greater than the odds among residents without children. The researchers also found that even greater support for sex offender residency restrictions occurred among 
residents with three or more children. The odds of residents with three or more children supporting these laws, in comparison to residents without children, increased to $70 \%$. Thus, the researchers concluded that "having multiple children (not just one child) significantly increases support for laws that prohibit where sex offenders can live, and this effect appears to be greater among parents with more children" (p. 1026).

Another explanation for widespread support of criminal justice policies aimed at sex offenders may be the popular misconception that sex offenders commonly victimize strangers. To determine whether or not such a misconception was related to sex offender registration, Craun and Theriot (2009) surveyed 565 community members in a single county in the southeastern United States. The experimental group $(n=242)$ was randomly selected from residences that were located within one-tenth of one mile from the listed address of at least one registered sex offender. The control group $(n=323)$ was selected from addresses that were at least one mile away from all registered sex offenders. The researchers found only about $14 \%$ of the entire sample (both the experimental and control group) reported that they were more concerned about someone they knew sexually assaulting a child. Fifty-six percent reported that they were equally concerned about a stranger and someone they knew, and about 30\% reported that they were more concerned about a stranger sexually assaulting a child than someone they knew. In terms of misconception percentages between groups, about $34 \%$ of the experimental group and about $27 \%$ of the control group were more concerned about strangers. Thus, the researchers concluded that in communities where registered sex offenders reside, awareness of a local sex offender significantly increases the likelihood that a community is more concerned about a stranger sexually assaulting a child. 


\section{Information Utilization and Awareness of Sex Offenders}

Although the general public commonly fears sex offenders and supports sex offender laws, a large majority of community members does not actively utilize available information that is disseminated through these policies. Anderson and Sample (2008) surveyed 1,821 adult Nebraska residents, and they found that most residents (89\%) were cognizant of the fact that a sex offender registry existed in their jurisdiction, but only about one-third (34\%) had used the sex offender registry. Similarly, from a survey of 733 Michigan residents, Kernsmith, Comartin, Craun, and Kernsmith (2009) found that only $37 \%$ had used the sex offender registry.

This limited utilization of publicly available information about sex offenders may subsequently reduce community members' awareness of sex offenders. In Kernsmith et al.'s (2009) study, nearly all residents (99\%) shared a zip code with a registered sex offender, but only $27 \%$ reported that they believed a sex offender lived in their community. Even among those residents who had accessed the state's sex offender registry, only $51 \%$ reported believing a sex offender lived in their community, and only one of these residents lived in a zip code in which no sex offender was registered.

Through mailed surveys with 631 residents in a single county in the southeastern United States, Craun (2010) focused on whether or not residents living near registered sex offenders were aware of their presence in the community. The experimental group ( $\mathrm{n}$ $=276$ ) was randomly selected from residences that were located within one-tenth of one mile from the listed address of at least one registered sex offender. The control group (n $=355)$ was selected from addresses that were at least one mile away from all registered sex offenders. She found that only $31 \%$ of residents who lived within one-tenth of one 
mile from a registered sex offender were aware of a sex offender in the area, as compared to only $2 \%$ of respondents in the control group. Even among those living directly adjacent to a registered sex offender, only about $44 \%$ were aware of their neighbor's status as a registered sex offender.

Likewise, utilizing door-to-door survey data from 95 community members in Illinois, Burchfield (2012) found that only $39 \%$ were aware that a sex offender resided in their neighborhood, in spite of the fact that $60 \%$ considered themselves to be familiar with the state's sex offender notification laws. Residents in the sample lived in ten Census block groups evenly divided between two suburban counties where at least one registered sex offender also resided. Thus, while community members are largely aware of criminal justice policies directed toward sex offenders, sex offender registration and community notification do not appear to raise actual public awareness of the presence of local sex offenders.

Regardless of whether members of the public use sex offender registries or know about sex offenders and sex offender laws, there is no consensus regarding the intended purpose of sex offender community notification. For instance, Zevitz and Farkas (2000a) focused on the experiences of Wisconsin residents who attended community meetings that accompanied sex offender community notification. During a nine month period, they administered surveys to 704 residents in attendance at 22 community notification meetings held throughout Wisconsin. They found that $59 \%$ believed community meetings were about a specific sex offender approaching release, while $29 \%$ felt the intention behind such meetings was to "soften the reaction to placing a sex offender in the community" (p. 398). Thus, both the absence of a clear focus associated with specific 
strategies and ill-informed citizens potentially render sex offender policies ineffective, in spite of their overwhelming support. Moreover, as a result of their attendance at a community meeting, $38 \%$ reported that they were more concerned about the presence of sex offenders in their community.

Evidence suggests that when the public is both aware of sex offenders and sex offender policies they display increased concern, which can also lead to excessive precautionary behavior. Through telephone surveys with 250 Alabama residents, Caputo and Brodsky (2004) investigated public reactions to sex offender registration and community notification. Residents who interpreted community notification as important reported using a greater number of coping strategies to deal with the close presence of sex offenders and reported being more fearful of general victimization, personal victimization, and sexual victimization. Those who were more afraid of victimization reported using more emotion-focused and problem-focused coping. However, from these findings, the researchers concluded that only "marginal support at best" existed for the argument that community notification laws were associated with precautionary actions against sexual victimization (p. 250).

Beck and Travis (2004) further examined whether sex offender registration and community notification policies were facilitating citizen use of precautionary measures against sexual victimization. They compared the behavior of 87 notified and 149 unnotified Ohio residents, and they found that those who had been notified of the close presence of a sex offender under the state's community notification law were significantly more likely to engage in precautionary actions. Notified residents were significantly more likely to add outside lighting to their home, learn more about self- 
defense strategies, warn a household member that strangers should not enter their home, and inform a household member that someone dangerous was living in the community. They also found that notified residents were more vigilant about local disorder issues, as such residents were significantly more likely to report suspicious and illegal behavior to the police.

Craun, Kernsmith, and Butler (2011) utilized telephone surveys with 728 Michigan residents to determine whether or not members of the general public supported extending criminal registries beyond sex offenders, and if so, with which types of offenders. Generally, findings reveal a split among respondents. Fifty-three percent reported that they supported additional, publicly available registries, nearly $43 \%$ reported that they did not want such registries, and $4 \%$ reported that they were undecided. Several indicators positively predicted community support for any type of additional registry. Residents who reported higher average scores on support for the requirement of registration for various types of sex offenders, those who had reported that they had accessed the state's sex offender registry, those who had reported that they were a victim of a sex offender, and those who had reported that they knew of someone who had been a victim of a sex offender were more likely to support the creation of additional criminal registries. Conversely, residents who reported that they were convicted of a criminal offense, in comparison to those who did not report that they were convicted of a criminal offense, were less likely to endorse additional criminal registries.

Thus, it may be important to examine the attitudes and beliefs of sex offenders themselves about various sex offender policies. Although criminal justice policies aimed at sex offenders are highly supported by the public, gaining the perspective of those who 
are subject to such policies may provide valuable insights into direct experiences with sex offender policies. Besides, prison wardens often interact with incarcerated sex offenders, and perceptions held by these individuals may be influential on wardens' views.

\section{Perceptions of Sex Offenders}

Some research has considered the perceptions of sex offenders with regard to sex offender policies. Studies soliciting the attitudes and beliefs of sex offenders suggest that such offenders occasionally recognize the potential value in sex offender policies. However, more often than not, sex offenders do not support criminal justice policies to which they are subject. A large majority report negative, collateral consequences associated with these policies, which may undermine their potential effectiveness.

Negative Experiences with Sex Offender Policies

Sex offenders from numerous qualitative studies have reported significant obstacles resulting from sex offender policies that have prevented them from easily reintegrating into society. Zevitz and Farkas (2000b) interviewed 30 registered sex offenders in Wisconsin about their perceived experiences with sex offender registration and community notification. Sex offenders described exclusion from their former residences, being ostracized by community members, threats, and harassment. Many sex offenders also discussed emotional harm to their family members, loss of employment, and added pressure from supervision officials resulting from community notification. In addition, a minority of sex offenders reported experiencing vigilante attacks.

To further examine potential negative ramifications associated with sex offender registration, Tewksbury and Lees (2006b) interviewed 22 registered sex offenders from Kentucky. Across their sample, they found that employment difficulties, relationships 
problems, harassment, social stigmatization, and persistent feelings of vulnerability emerged as pervasive experiences. It is also important to note that the researchers believed these issues were experienced more prevalently by the sex offenders in their study than prior literature had suggested for other types of convicted felons. As a result, they concluded that registered sex offenders may experience a more challenging reintegration process.

Setbacks associated with sex offender registration may include problems with social relationships and increased stress. Robbers (2009) used qualitative interviews and surveys with a sample of 153 sex offenders. She showed that the experience of being socially stigmatized and publicly shamed through sex offender policies has serious negative impacts on a sex offender's community involvement. Specifically, she concluded that the experience of sex offender registration reduced social support, created the loss of family relationships and identity as an active citizen, and increased psychological stress.

Most recently, to gauge the degree to which stigmatization is experienced, Tewksbury (in press) utilized semi-structured interviews with 24 incarcerated sex offenders approaching their release dates. His analysis focused on how sex offenders recognized social stigmatization and potential responses to such public labeling. Sex offenders largely reported shame, hopelessness, depression, and fear resulting from perceptions of stigmatization received from both prison and society. In addition, sex offenders commonly expressed resentment towards those they perceived as labeling them. These descriptions by sex offenders are important to consider because public 
labeling is a significant component to sex offender registration and community notification.

Research has pointed to numerous collateral consequences directly associated with criminal convictions. These collateral consequences are the unfavorable experiences that may exist in association with criminal penalties (Buckler \& Travis, 2003; Wheelock, 2005). Most research has approached collateral consequences from the perspective of general felony convictions. Social consequences are largely apparent in the additional, supposedly unintended, outcomes resulting from felony convictions. These issues include stigmatization, employment difficulties, relationship problems, and negative feelings regarding self-image (Dodge \& Pogrebin, 2001; Pogrebin, Dodge, \& Katsampes, 2001).

Extensively interviewing male parolees, Harding (2003) examined the way in which former inmates managed their felonious identity. The ex-convicts revealed that social consequences, particularly stigmatization of convicted felons, make societal reintegration extremely difficult. Academic works concerning felony convictions have also pinpointed numerous legal repercussions, which include employment restrictions, loss of voting rights, and other civil limitations (Burton, Cullen, \& Travis, 1987; Olivares, Burton, \& Cullen, 1996).

Recent studies indicate that the nature and degree of collateral consequences for sex offenders may be greater than for other convicted felons. Drawing on data from 121 registered sex offenders, Tewksbury (2005) found that loss of relationships, employment, and housing, as well as social stigmatization, was experienced by a significant minority of registered sex offenders. The most prominent finding was that more than one-half 
(54\%) believed that they lost a friend as a result of registration and public knowledge of their sexual offending. In addition, $47 \%$ were harassed in person, $45 \%$ lost or were denied a place to live, and $42 \%$ lost a job.

Likewise, Levenson and Cotter (2005a) surveyed 183 sex offenders in Florida to examine the experiences and consequences of sex offender registration and community notification. Their results are similar to Tewksbury's (2005) findings, as they report that as a result of their status as registered sex offenders, $35 \%$ of the sample was required to relocate to a new residence, $27 \%$ lost their job, and $19 \%$ experienced harassment in some form. These same researchers (Levenson \& Cotter, 2005b) explored the impact of sex offender residency restrictions by surveying 135 sex offenders in Florida. Fifty-seven percent found it difficult to locate affordable housing, $44 \%$ were unable to live with family members, and approximately $25 \%$ reported that they had to relocate their residence as a result of the state's residency restriction law. Sixty percent of the sex offenders in the study also expressed emotional distress as a direct outcome of the residency restrictions to which they were subject.

Brannon, Levenson, Fortney, and Baker (2008) have shown that, when comparing perceptions and experiences of sex offenders and community residents, sex offenders report far more negative experiences arising from registration than is realized by the public. Almost one-half of sex offenders reported experiencing threats, property damage, and physical assault, while only $10 \%$ of residents were aware of such vigilantism resulting from public disclosure. Correspondingly, in Schiavone and Jeglic's study (2009), only $17 \%$ of the public believed that sex offender registration made sex offenders' reintegration more stressful. 
Additionally, Tewksbury and Lees (2006a) examined the experiences of an important subset of registered sex offenders - those listed on university-maintained sex offender registries. Through surveys of such registrants, they found high levels of collateral consequences. Specifically, they reported that $65 \%$ of these sex offenders were not hired or lost a job, $42 \%$ lost or were denied a place to live, and $42 \%$ lost a friend as a result of their registration status.

Such adverse consequences are again seen in Tewksbury's (2004) study, where he examined the experiences and perceptions of 40 female sex offenders in Kentucky. From the experiences of these women, the researcher found that "far-reaching implications" existed for "individuals listed on registries" (p. 32). Specifically, a number of negative experiences resulted from sex offender registration. Forty-two percent lost a job, 39\% lost a friend, and $34 \%$ were harassed in person as a result of registration and public knowledge of their sex offenses. At the same time, $34 \%$ lost or were denied a place to live.

When these studies are taken together, a significant minority of sex offenders exposed to registration, community notification, and residency restrictions experience associated negative, unintended consequences that make societal reintegration more challenging. These repercussions of sex offender laws may also negatively impact how sex offenders view such policies and their overall effectiveness to prevent sexual victimization.

\section{Views about Sex Offender Policies}

Some research on sex offenders' perceptions of sex offender policies has suggested that many sex offenders are unfamiliar with such policies. Elbogen, Patry, and 
Scalora (2003) examined sex offenders' knowledge and perceptions of sex offender community notification laws. They surveyed 40 sex offenders living in a Nebraska residential treatment facility. Forty-eight percent reported that they were unfamiliar with the Nebraska community notification law, and $49 \%$ were unfamiliar with the factors used to determine which sex offenders would be subject to community notification. This lack of familiarity with sex offender policies is consistent with the work of Tewksbury and Lees (2006a), where $61 \%$ of sex offenders did not know that they were registered on a university sex offender registry.

However, most research has shown that sex offenders generally believe registration, community notification, and residency restrictions are unfair and ineffective. In Elbogen et al.'s (2003) study, home telephone number (83\%), home address (73\%), and work address $(70 \%)$ were items considered by sex offenders as unfair to release to the public. This is consistent with Levenson and Cotter's (2005a) study, where less than $10 \%$ of sex offenders believed it was fair for their home telephone number, home address, work address, or vehicle description to be known. Brannon et al. (2008) found that sex offenders $(70 \%)$ believed community notification was more unfair than the general public (22\%). In addition, Tewksbury (in press) noted that sex offenders approaching release generally believed their public labeling was unfair.

Focusing on the perceived effectiveness of sex offender registration, Tewksbury and Lees (2007) interviewed 22 sex offenders in Kentucky. Generally, sex offenders supported the existence of a publicly available sex offender registry. Although sex offenders recognized such registries as potential tools for public safety, such as making community members aware of sex offender presence and deterring recidivism, they 
mostly did not believe that the state's sex offender registry was effective in its current form. Numerous sex offenders suggested that many community members may not be aware of sex offender registries, and if they were cognizant of and used them, such community members may not use them for its intended purpose. Sex offenders believed that an offense-based classification system, input from officials regarding length of time necessary for registration, and increased restrictions about who can access registry information and for what purposes may improve sex offender registration.

Similarly, Zevitz and Farkas (2000b) found that registered sex offenders expressed their skepticism about the deterrent value of community notification and believed that such a law hindered their progress. In fact, most interviewed sex offenders believed that registration and community notification would not deter future sexual victimization. Correspondingly, Brannon et al. (2008) reported that sex offenders (42\%), in comparison to the general public (10\%), viewed community notification as less effective at reducing sex offenses.

Further highlighting the perceived ineffectiveness of sex offender policies, Tewksbury's (2006) survey from Kentucky concluded that sex offenders, by means of the state's publicly available registry, were not closely monitored by the community or law enforcement. As a result of their status as registered sex offenders, $61 \%$ believed they were recognized in public only a few times annually or less, while $31 \%$ felt they had never been publicly recognized. Similarly, $56 \%$ of registered sex offenders on college campuses with campus-specific registries reported being recognized only a few times per year (Tewksbury \& Lees, 2006a). Further, in Tewksbury's (2006) study, 35\% of 
registered sex offenders reported that they were never contacted by law enforcement, while $26 \%$ reported that they were contacted only once annually.

This lack of monitoring through sex offender registration and accompanying restrictions calls into question the effectiveness of such policies implemented and enforced by criminal justice system actors. Thus, it may be important to examine the attitudes and beliefs of criminal justice system actors about various sex offender policies. After all, these individuals are responsible for implementation and enforcement of sex offender policies, and they may have direct experiences with such policies that are distinct from those of sex offenders.

\section{Perceptions of Criminal Justice System Actors}

Few studies examine the attitudes and beliefs of criminal justice system actors who are responsible for the supervision of sex offenders and the implementation and enforcement of sex offender policies. Available research focuses on the perceptions of legislators, judges, law enforcement officers, correctional officers, parole board members, and community corrections professionals. In sum, these populations commonly hold negative views about sex offenders. At the same time, criminal justice system actors have generally positive, although occasionally mixed, perceptions about the value and efficacy of sex offender policies.

\section{Attitudes and Beliefs about Sex Offenders}

Research has shown that criminal justice system actors largely hold negative views about sex offenders. This is not surprising, as most members of the general public hold negative perceptions of sex offenders (e.g., Kernsmith et al., 2009; Levenson et al., 2007). However, among criminal justice system actors, it appears that as groups engage 
in more and more intensive, direct contact with sex offenders, they tend to hold more positive views of such offenders. Looking at a mixed group of criminal justice system actors, Hogue (2003) surveyed law enforcement officers, correctional officers, probation officers, psychologists, and sex offenders about their perceptions of sex offenders. Overall, each group significantly differed in their collective attitudes and beliefs about sex offenders. Sex offenders reported the most positive attitudes and beliefs. Among correctional officers, those involved in sex offender treatment indicated more positive views than those who were not involved in such treatment. Probation officers and psychologists held more positive perceptions than correctional officers, while law enforcement officers reported the most negative attitudes and beliefs. This is consistent with Lea, Auburn, and Kibblewhite's (1999) study, which found that law enforcement officers, who had the least amount of direct experience with sex offenders, were more likely to hold negative attitudes and beliefs about such offenders.

Redlich (2001) also found that law enforcement officers held negative views of sex offenders and perceptions that are more negative than those of community members. Specifically, she compared the attitudes and beliefs of 109 community members with those of 78 law enforcement officers and 82 law students. Community members and law students were significantly more likely than law enforcement officers to believe that sex offenders could be rehabilitated.

Judges have also been shown to hold negative perceptions about sex offenders. Bumby and Maddox (1999) surveyed 42 Midwestern trial judges to assess their attitudes and beliefs toward sex offenders. Sixty-six percent reported that they would strongly oppose the release of a sex offender into their neighborhood, and $41 \%$ did not believe that 
sex offenders received long enough sentences. Interestingly, none of the judges believed that the sex offense for which an individual was arrested was their first act of sexual offending.

Weekes, Pelletier, and Beaudette (1995) showed that sex offenders are generally seen as more dangerous, harmful, and violent than offenders convicted of other types of offenses. Eighty-two correctional officers from two Canadian federal correctional institutions rated their perceptions of three types of criminal offenders: sex offenders against women, sex offenders against children, and offenders that were not convicted of sex offenses. Results from a standardized, 19-item scale indicated that sex offenders were viewed much more negatively than non-sex offenders. Sex offenders against children were seen as significantly more immoral and mentally ill than sex offenders against women, whereas sex offenders against women were seen as significantly more immoral and mentally ill than non-sex offenders.

In order to better understand perceptions of community members about sex offenders, such as those reported in Weekes et al.'s (1995) study, Church, Wakeman, Miller, Clements, and Sun (2008) developed and refined a multi-item scale for examining attitudes and beliefs about sex offenders. Their Community Attitudes Toward Sex Offenders (CATSO) scale is composed of four factors or components that can summarize basic views toward sex offenders. These four components (i.e., Social Isolation, Capacity to Change, Severity/Dangerousness, and Deviancy) are presented as a way to most efficiently understand the types of degrees of perceptions held by community members. Importantly, Church and colleagues (2008) suggest that the CATSO scale 
should also be efficient and effective at assessing the views of criminal justice system actors.

As a result, several studies have examined the utility of the CATSO scale for understanding the views of specific criminal justice system actors, and all have found significant problems with applying the scale to such respondents. Tewksbury and Mustaine (2011) drew on surveys with 80 parole board members from 30 of the 48 states with a parole board and show problems in application. Tewksbury et al. (in press) also showed that the CATSO scale does not work well with community corrections professionals, as they largely did not associate sex offenders with inherent social isolation, considered sex offenders to be capable of change, viewed sex offenders as serious criminals who are especially dangerous, and did not consider sex offenders to be more deviant or sexually preoccupied than other individuals. An additional study (Conley, Hill, Church, Stoeckel, \& Allen, 2011) surveyed community corrections professionals with the same methodology and found similar results. Thus, while there is limited understanding of the views of criminal justice system actors regarding sex offenders, a lack of support remains for the existing instrument designed to assess this population. There is a need to further investigate the views and experiences of other criminal justice system actors.

\section{Perceptions of Sex Offender Policies}

Although criminal justice system actors primarily hold negative attitudes and beliefs about sex offenders, these individuals appear to have largely positive views regarding sex offender policies. Finn (1997) conducted telephone interviews with 13 criminal justice practitioners from eight different jurisdictions. His sample included 
probation officers, law enforcement officers, and prosecutors. These individuals considered community notification aimed at registered sex offenders to be a valuable supervision mechanism. At the same time, they felt that such procedures both successfully assist law enforcement investigation and educate community members about sexual victimization. Interestingly, however, most practitioners recognized that sex offenders should not be required to implement the actual notification themselves, as it may frighten community members.

Considerable judicial support has been revealed for sex offender registration and community notification. In Bumby and Maddox's (1999) study, $85 \%$ of judges believed that sex offenders should be obligated to register with law enforcement, and $70 \%$ felt that prisons and hospitals should be required to notify communities about a sex offender's release. Only $26 \%$ believed that sex offender community notification laws were unfair. Research also shows that law enforcement officers strongly endorse sex offender policies. In Redlich's (2001) study, law enforcement officers, in comparison to community members and law students, were more likely to believe sex offender community notification did not violate a sex offender's rights and was effective in preventing child sexual victimization. Law enforcement officers also expressed the most support for sex offender community notification laws, and law students indicated the least support for such policies. Although law students were the most likely to think community members would harm known sex offenders, law enforcement officers and community members did not differ in their views. In addition, and perhaps most importantly, among all three groups, respondents with more accurate knowledge of sex 
offenders and sex offenses were less likely to support sex offender registration and community notification.

Tewksbury and Mustaine's (2011) survey of parole board members showed that such individuals support sex offender registration and community notification as policies, in spite of questioning their efficacy and scope. However, these actors did not generally endorse Internet-based, publicly available sex offender registries, but instead favored community notification through available lists of sex offenders maintained at law enforcement agencies. When compared with parole board members, a significantly larger proportion of community corrections professionals in Tewksbury et al.'s (2011) study believed that community notification laws are fair and sex offender policies are effective in reducing the number of sex offenses. Based on their assessment of perceptions among a national sample of 716 community corrections professionals, the researchers found more support for sex offender policies than was present among parole board members. Similarly, Datz (2009) reported that probation and parole officers saw electronic monitoring, restrictions and conditions based on risk, and public notification as the most effective sex offender policies.

Legislators have mixed attitudes and beliefs about sex offender laws, but it appears that their own personal viewpoints have a significant impact on their perceptions of such policies. This is important because legislators, who are responsible for creating sex offender policies, are admittedly unable to make decisions without relying on their own values and beliefs. Sample and Kadleck (2011) interviewed 25 Illinois legislators and state government officials about their perceptions of sex offender policies. They found a wide range of views on the suitability and effectiveness of sex offender 
registration and community notification. Some legislators expressed that sex offender laws were overly punitive, while others felt such criminal justice policies should be strengthened. However, it was also found that perceptions of sex offender laws were impacted by an individual's own beliefs and values. At the same time, members of the general public may be equally influential, as many reportedly influenced the legislative process by informing legislators of events and subsequently asking for action. Further, all interviewees admitted to relying on the media to inform them of events, trends, and criminal justice statistics. Thus, the media may also serve as an indirect influence on the attitudes and beliefs of these public officials.

It is important to recognize that some criminal justice system actors see sex offender policies as having questionable utility and value, as well as making societal reintegration more difficult for sex offenders. Gaines (2006) showed that law enforcement officers, who are responsible for implementing community notification procedures, acknowledge that sex offender registration and community notification prove to be burdensome for sex offenders. Datz's (2009) study of probation and parole officers in Florida found that community corrections professionals see several problems associated with sex offender registration and community notification. Included among these problems is a belief that residency restrictions cause numerous sex offenders to become homeless. Nearly three-quarters of her sample believed residency restrictions were the most daunting obstacle for supervised sex offenders, and $20 \%$ reported having a homeless sex offender on their caseload abscond from supervision.

Nonetheless, criminal justice system actors appear to hold more positive views about sex offender policies, even when compared with other professionals. Levenson, 
Fortney, and Baker (2010) asked individuals working in the field of sexual abuse (including law enforcement officers, probation officers, attorneys, and polygraph examiners) a series of questions designed to elicit their perceptions about sex offender policies. The researchers compared criminal justice professionals with other (e.g., mental health) professionals in the sample who worked closely with sex offenders. Criminal justice professionals (38\%) were significantly more likely than other professionals (29\%) to agree with community notification, and criminal justice professionals (71\%) were significantly more likely than other professionals (34\%) to believe all sex offenders should be subject to community notification laws. Fewer criminal justice professionals ( $20 \%$ in comparison to $53 \%$ of other professionals) believed sex offender community notification laws were unfair, and more criminal justice professionals ( $71 \%$ in comparison to $34 \%$ of other professionals) reported that they would support sex offender policies without scientific evidence that such laws were effective.

\section{Perceptions of Prison Wardens}

Research on the perceptions of prison wardens, about any topic, is almost nonexistent. Besides the present research, only two identified studies have examined the attitudes and beliefs of wardens. Such research examined wardens' views regarding both the prevalence of prison sex and inmate fear of sexual assault. These studies are germane to the present research because they also attempted to capture perceptions of this population through a survey methodology.

Focusing on prison sexual violence, Hensley and Tewksbury (2005a) examined whether or not, and to what degree, individual demographic variables and institutional characteristic variables were associated with prison wardens' perceptions of the 
prevalence of sexual assault in their institutions. They used data collected from anonymous surveys of 226 prison wardens from state-operated institutions. Overall, wardens did not believe that there was a significant level of sexual activity (consensual or coercive) taking place in their institutions. None of the individual demographic or institutional characteristic variables were statistically related to wardens' perceptions of coercive sexual activities among inmates. According to the researchers, "this suggests that the job demands, typical preparation and/or training, and culture of being a warden are fairly consistent, at least in regard to perceptions of institutional sexual assaults" ( $p$. 194).

However, with correlational analysis, four independent variables (i.e., gender, race, sex of prison, and ratio of correctional officers to inmates) were correlated with wardens' perceptions of the amount of consensual sexual activity between inmates. Female and non-White wardens were more likely to report that a higher percentage of inmates had consensual sex in their institutions compared to male and non-White wardens. Wardens supervising all-female and mixed correctional institutions were more likely to report that a higher percentage of inmates had consensual sex in their institutions compared to wardens supervising all-male correctional facilities. And, wardens from prisons with a higher inmate-to-correctional-staff ratio were more likely to report that a higher percentage of inmates had consensual sex compared to wardens from prisons with a lower inmate-to-correctional-staff ratio.

From the same sample, Tewksbury and Hensley (2005b) examined prison wardens' perceptions of inmate fear of sexual assault in their institutions. From a 10point scale (no inmate fear $=1$ to extreme inmate fear $=10)$ wardens were asked to 
indicate, "How prevalent do you believe fear of sexual assault is among the inmates in your institution?" Generally, wardens believed that the prevalence of inmate fear of sexual assault was relatively low (as indicated by one, two, and three responses). Nearly $65 \%$ of the wardens believed that fear of sexual assault within their prisons was low, and only $10 \%$ felt that inmate fear of sexual assault was high in their prisons (as indicated by seven, eight, and nine responses). Using multiple regression analysis, the strongest predictors of warden's perceptions of prevalent inmate fear of sexual assault was sex of institution (all-male), security level (high), and number of officially reported inmate sexual assaults in prison (high).

\section{The Present Study}

There is relatively little known about how criminal justice actors perceive sex offenders and the fairness, efficacy, and scope of sex offender policies aimed at sex offenders. Similarly, there is very little research that specifically examines the attitudes, beliefs, perceptions, and experiences of prison wardens. Following in the footsteps of earlier research (Tewksbury \& Mustaine, 2011; Tewksbury et al., 2011, in press), the present study will address these gaps by considering the attitudes and beliefs toward sex offenders held by prison wardens. This examination will include perceptions about sex offenders as prison inmates, sex offender registration, community notification, and residency restrictions. Further, this research will assess the utility of the 18-item Community Attitudes Toward Sex Offenders (CATSO) scale (Church et al., 2008), which was advocated for use with criminal justice actors, to determine whether or not the instrument can be effectively utilized with prison wardens. This is an important population to examine, as such individuals occupy important leadership roles in 
corrections, having a great deal of power and influence on the criminal justice experience of sex offenders. 


\section{CHAPTER II}

\section{METHODS}

The purpose of this study is to advance the understanding of how prison wardens understand, perceive, and respond to sex offenders, sex offender registration, community notification, and residency restrictions. To do this, the present research examines the attitudes and beliefs of wardens through survey methodology. The utility of the CATSO scale (Church et al., 2008) will also be assessed with data from wardens to determine whether or not the instrument can be effectively utilized with this specific population. By surveying wardens, who occupy critical leadership roles in corrections, this study follows previous sex offender perception research (e.g., Tewksbury \& Mustaine, 2011; Tewksbury et al., in press) to examine another, equally important, criminal justice population.

Data for the present analysis originate from voluntary, anonymous surveys administered to state prison wardens employed at various jurisdictions throughout the United States. The surveys attempt to gauge how wardens understand, perceive, and respond to the management of sex offenders in both correctional institutions and the community. The questionnaire consists of 57 items, and it was estimated to take approximately 5 to 10 minutes to complete.

Initially, prison wardens were informed of the online survey through an e-mail invitation from the researcher. The announcement notified wardens of the study, encouraged their participation, and provided a link to the online survey. One month after 
the e-mail invitations were sent, this approach generated only five completed surveys. These five online surveys were completed by wardens within three of the 19 randomly selected jurisdictions described below. As a result, a new strategy utilizing hard copy surveys was implemented to increase the likelihood of responses.

Prison wardens received mail packets that contained a cover letter, a hard copy of the survey instrument, and a postage-paid, self-addressed return envelope. In an effort to encourage participation, each cover letter included a distinct salutation (i.e., full name of the warden and associated institution) and informed wardens that their cooperation may help scholars and policymakers to better understand sex offenders as correctional clients. This strategy proved to be more successful. Prior to data collection, all procedures and materials were reviewed by the researcher's institutional review board.

\section{Sample}

In order to enlist respondents in the study, the researcher contacted prison wardens at their respective institutions through postal mail. All contact information, including the mailing addresses of wardens, was amassed from the American Correctional Association's Directory of Adult and Juvenile Correctional Departments, Institutions, Agencies, and Probation and Parole Authorities (2010). This publication served as the sampling frame, and the information contained therein was verified through online jurisdictional resources, primarily the webpages of correctional entities, which helped to ensure accuracy and timeliness.

The target population for this study included all prison wardens in all 50 states responsible for state-operated adult correctional institutions. Wardens located at federal correctional facilities, private correctional institutions, prerelease centers, and juvenile 
detention facilities were excluded. Preliminary investigation from August 2011 revealed 821 such wardens. However, due to limited financial resources, a more feasible sampling procedure was necessary.

As a result, 19 statewide correctional jurisdictions were randomly selected for inclusion in the present study. Among these jurisdictions, all four geographic regions in the United States were represented: Midwest $(n=4)$; Northeast $(n=2)$; South $(n=6)$; and West $(n=7)$. All 240 prison wardens $(29.2 \%$ of total) from these jurisdictions responsible for state-operated adult correctional facilities were invited to participate in the study. A total of 68 wardens (5 online and 63 hard copy) submitted completed surveys. This represents a $28.3 \%$ response rate. ${ }^{1}$

Table 1 shows the demographic characteristics of the sample. Respondents are largely male (83.8\%), White (76.1\%), and married/partnered (83.6\%). Overall, they range in age from 37 to 65 , with a mean age of 52.0 years. Interestingly, most respondents $(91.0 \%)$ possess a two- or four-year college degree. Of these respondents, more than one-half (52.2\%) hold a four-year college degree, and nearly one-third (32.8\%) have also completed a graduate degree, and a small proportion has a two-year college degree $(6.0 \%)$. The remaining respondents $(9.0 \%)$ have some college experience. Thus, each respondent has at least some education at the postsecondary level.

It is also important to note that most respondents $(90.6 \%)$ have children, and more than one-third (34.4\%) have minor children (under the age of 18). Respondents have an average of more than eight years of experience as a prison warden, and their political

\footnotetext{
${ }^{1}$ This less-than-desirable response rate is acknowledged. However, previous studies concerning perceptions of sex offenders and sex offender policies are also limited by lower response rates (Kernsmith, et al., 2009; Levenson \& Cotter, 2005; Levenson \& Tewksbury, 2009; Tewksbury, 2004, 2005; Tewksbury \& Humkey, 2010; Tewksbury \& Mustaine, 2011).
} 
views are self-characterized as more conservative than liberal. The respondents represent each of the 19 randomly selected jurisdictions in the United States.

\section{Table 1}

\section{$\underline{\text { Sample Characteristics }}$}

Variable

Value

Sex

Male

$83.8 \%(\mathrm{n}=57)$

Female

$$
16.2 \%(\mathrm{n}=11)
$$

Race

White

$76.1 \%(\mathrm{n}=51)$

Black

$16.4 \%(\mathrm{n}=11)$

Hispanic/Latino

$$
6.0 \%(n=4)
$$

Mixed Race

$$
1.5 \%(\mathrm{n}=1)
$$

Age (mean)

$52.0(\mathrm{n}=66)$

Marital status

Married/partnered

$83.6 \%(n=56)$

Divorced/separated

$11.9 \%(\mathrm{n}=8)$

Single/never married

$4.5 \%(n=3)$

Have children

$90.6 \%(n=6)$

Have minor children

$34.4 \%(n=26)$

Education

Four-year college degree

$52.2 \%(\mathrm{n}=35)$

Graduate degree

$32.8 \%(n=22)$ 
Some college

Two-year college degree

Tenure as prison warden (mean)

Self-identified political orientation (mean)

(very liberal $=1$, very conservative $=7$ )
$9.0 \%(\mathrm{n}=6)$

$6.0 \%(n=4)$

8.8 years $(n=64)$

$4.7(n=68)$

\section{Instrument and Measures}

The data collection instrument contains items both specifically designed for this study and borrowed from previous sex offender perception research (Church et al., 2008; Tewksbury \& Mustaine, 2011). Both the online and hard copy versions, which consist of 57 total items, are identical. The hard copy version is a four-page (the front and back sides of two pages) questionnaire. The format of survey items changes periodically within the instrument to facilitate thoughtful responses.

The first 16 items on the survey were created for the present research. These items measure a respondent's views of sex offenders as prison inmates, sex offender survival strategies, and institutional sex offender treatment programs. Each of these prison-specific items presents a statement, and respondents are invited to indicate whether they strongly agree, agree, disagree, or strongly disagree with each statement. Responses to these items were coded at the ordinal level (strongly agree $=1$, agree $=2$, disagree $=3$, strongly disagree $=4$ ).

Besides the prison-focused statements, the instrument also contains 12 items that were originally developed by Tewksbury and Mustaine (2011) to measure criminal justice system actors' attitudes and beliefs about sex offenders and sex offender policies. Six of these survey items specifically measure a respondent's views on sex offender 
registration, community notification, and residency restrictions. The first such item asks wardens what should be reported on a registrant's sex offender registry page.

Respondents are presented with 14 variables (i.e., name, photograph, fingerprints, home address, with whom the sex offender lives, home telephone number, vehicle description, vehicle license plate number, description of offense(s), work location/address, victim(s) name(s), victim(s) age(s), victim(s) gender(s), and HIV/STD test results for the sex offender), and they are invited to select whether or not such registry items should be included. Responses to this item were coded at the nominal level $($ no $=0$, yes $=1)$. For the second item, wardens are asked how to best conduct community notification. Respondents are presented with eight variables (i.e., media releases/announcements, door-to-door information from the police/sheriff, mailed or posted flyers, registration lists at law enforcement agencies, registration lists on the Internet, community meetings, automated telephone calls to residents, and information should be provided by the police only upon request), and they are invited to select whether or not they support such notification methods. Responses to this item were coded at the nominal level (no $=0$, yes $=1$ ).

Wardens, in the third item, are asked which child congregation locations are appropriate sites for which to prohibit sex offenders from living near. Respondents are presented with ten variables (i.e., schools, daycares, parks, fast food restaurants, school bus stops, youth athletic fields, skateboard parks, public swimming pools, public restrooms, and public libraries), and they are invited to select whether or not sex offenders should be restricted from living near such locations. Responses to this item were coded at the nominal level (no $=0$, yes $=1$ ). In the fourth item, wardens are asked 
which types of sex offenders should be subject to community notification, and responses to this item were coded at the ordinal level (no sex offenders $=0$, only sex offenders with high risk assessment scores $=1$, all sex offenders $=2$ ).

For the fifth item, wardens are asked whether or not they believe community notification laws are fair, and responses to this item were initially coded at the ordinal level (unfair $=1$, somewhat unfair $=2$, mostly fair $=3$, fair $=4$ ). Wardens consider such laws to be fair (58.8\%), mostly fair (29.4\%), somewhat unfair (8.8\%), and unfair $(2.9 \%)$. Responses to this item are clearly skewed, and there is a lack of variation across the four categories. Because it is used as a dependent variable in a logistic regression for determining potential sources of wardens' perceptions, this item was subsequently coded as a dichotomous variable (unfair/somewhat unfair $=0$, mostly fair/fair $=1$ ).

Wardens, in the sixth item, are asked whether or not community notification is effective in reducing the number of sex offenses, and responses to this item were initially coded at the ordinal level (agree, community notification is very effective at reducing sex offenses $=1$, somewhat agree, community notification creates some reduction $=2$, somewhat disagree, community notification creates a little bit of a reduction $=3$, disagree, community notification does not create a reduction $=4$ ). Wardens believe community notification is very effective at reducing sex offenses $(9.0 \%)$, creates some reduction $(50.7 \%)$, creates a little bit of a reduction (16.4\%), and does not create a reduction $(23.9 \%)$. Because the item was used as a dependent variable in a logistic regression for determining potential sources of wardens' perceptions, this item was subsequently coded as a dichotomous variable (disagree/somewhat disagree $=0$, agree/somewhat agree $=1$ ). 
Five survey items specifically measure a respondent's perceptions about certain laws aimed at the prevention of sex offenses. Each of these items presents a statement, and respondents are invited to indicate whether they strongly agree, agree, disagree, or strongly disagree with each statement. These statements are included in the present instrument. Wardens are asked whether or not they would support sex offender residency restrictions with no scientific evidence that such laws are effective in preventing victimization, whether or not laws that prevent sex offenders from living near child congregation locations are effective in preventing sexual victimization, and whether or not sex offender registration and notification is effective in preventing sexual victimization. In addition, they are asked whether or not placement on a publicly available sex offender registry deters sex offenders from sex offending, and whether or not placement of sex offenders on a publicly available sex offender registry deters general members of the community from sex offending. Responses to these five items were coded at the ordinal level (strongly agree $=1$, agree $=2$, disagree $=3$, strongly disagree $=4$ ).

The last survey item specifically measures a respondent's perspective on sex offender recidivism. Incorporating this into the present instrument, wardens are asked how likely a sex offender is to reoffend in comparison to the general criminal population, and responses to this item were initially coded at the ordinal level (at a much lower rate $=$ 1 , at a slightly lower rate $=2$, at the same rate $=3$, at a slightly higher rate $=4$, at a much higher rate $=5)$. Wardens believe sex offenders recidivate at a much lower rate $(3.0 \%)$, a slightly lower rate (19.4\%), the same rate (28.4\%), a slightly higher rate $(31.3 \%)$, and a much higher rate $(17.9 \%)$. Relatively few respondents chose the more extreme answer 
choices and instead selected more moderate answer choices. Because it was used as a dependent variable in a logistic regression for determining potential sources of wardens' perceptions, this item was subsequently coded as a dichotomous variable (sex offenders recidivate at a much lower/lower rate than other criminals $=0$, sex offenders recidivate at the same rate $=$ missing, sex offenders recidivate at a much higher/higher rate than other criminals $=1)$

In addition, the instrument contains the 18-item Community Attitudes Toward Sex Offenders (CATSO) scale (Church et al., 2008). This scale was developed to evaluate attitudes and beliefs about sex offenders across various populations, and it consists of four subscales with corresponding items. The present instrument uses these 18 items verbatim to further assess wardens' perceptions of sex offenders. Each of these items presents a statement, and respondents are asked whether they strongly agree, agree, disagree, or strongly disagree with each statement. Responses to these items were coded at the ordinal level (strongly agree $=1$, agree $=2$, disagree $=3$, strongly disagree $=4$ ). As noted below, three items were reverse coded (strongly agree $=4$, agree $=3$, disagree $=$ 2 , strongly disagree $=1)$.

The first subscale, Social Isolation, includes the following statements: (1) Sex offenders have difficulty making friends even if they try real hard; (2) Most sex offenders do not have close friends; (3) Most sex offenders keep to themselves; (4) Sex offenders prefer to stay home alone, rather than be around lots of people; and (5) Most sex offenders are unmarried men. Capacity to Change, which is the second subscale, includes the following statements: (1) Convicted sex offenders should never be released from prison; (2) Sex offenders should wear tracking devices, so their location can be 
pinpointed at any time; (3) People who commit sex offenses should lose their civil rights;

(4) Trying to rehabilitate a sex offender is a waste of time; and (5) With support and therapy, someone who committed a sexual offense can learn to change their behavior (reverse coded).

The third subscale, Severity/Dangerousness, includes the following statements:

(1) A sex offense committed against someone the perpetrator knows is less serious than a sex offense committed against a stranger; (2) Only a few sex offenders are dangerous (reverse coded); (3) Someone who uses emotional control when committing a sex offense is not as bad as someone who uses physical control when committing a sex offense; (4) The prison sentences sex offenders receive are much too long when compared to the sentence lengths for other crimes (reverse coded); and (5) Male sex offenders should be punished more severely than female sex offenders. The fourth subscale, Deviancy, includes the following statements: (1) Sexual fondling (inappropriate, unwarranted touch) is not as bad as rape; (2) Sex offenders have high rates of sexual activity; and (3) People who commit sex offenses want to have sex more often than the average person.

Lastly, the instrument includes eleven items regarding demographics, experience, and self-reported political views. Respondents are asked to indicate their sex, and the responses to this item were coded at the nominal level $($ female $=0$, male $=1)$. Respondents are invited to indicate their race, and responses to this item were coded at the nominal level $($ White $=1$, Black $=2$, Native American $=3$, Asian $=4$, Mixed Race $=$ 5 , Other $=6$ ). Respondents are asked whether or not they consider themselves to be Hispanic/Latino, and responses to this item were coded at the nominal level (no $=0$, yes $=1$ ). Respondents are invited to indicate their age, and responses to this item were coded 
at the ratio level (as a whole number in years). Respondents are invited to indicate their marital status, and responses to this item were coded at the nominal level (single/never married $=1$, married $/$ partnered $=2$, divorced $/$ separated $=3$, widowed $=4$ ). Respondents are invited to indicate their total number of children and their total number of minor children, and responses to these items were coded at the ratio level (as a whole number). Respondents are invited to select their level of education, and responses to this item were coded at the ordinal level (some high school $=1$, high school graduate $=2$, some college $=3$, two-year college degree $=4$, four-year college degree $=5$, graduate degree $=6$ ) Respondents are invited to indicate the number of years they have served as a prison warden, and responses to this item are coded at the ratio level (as a whole number in years). Respondents are asked to provide their self-reported political views, and responses to this item are measured on a seven-point Likert scale (very liberal $=1$ to very conservative $=7$ ). Finally, respondents are asked to identify the state in which they are employed as a prison warden, and responses to this item are coded at the nominal level to determine response rate.

Besides describing the sample, most of the items pertaining to demographics, experience, and self-reported political views also serve as independent variables in three logistic regression models. Specifically, eight separate items are utilized as predictor variables to measure demographic, experiential, and political influences on perspectives about sex offenders. For the logistic regression analyses, the coding scheme remained unchanged for a respondent's sex, age, education, number of children, experience, and political orientation. However, a respondent's marital status (not married $=0$, married $=$ $1)$ is dichotomized. Most prison wardens $(92.5 \%)$ in the sample are White or Black, and 
very few $(6.0 \%)$ indicate they are also Hispanic/Latino. For this reason, in an attempt to generate a meaningful interpretation, a respondent's race (White $=0$, Other $=1$ ) was also dichotomized. This is consistent with prior sex offender perception research (Tewksbury \& Mustaine, 2011).

\section{Data Analysis Strategy}

\section{Descriptive Statistics}

The analysis begins by using measures of central tendency to describe prison wardens' attitudes and beliefs about sex offenders and sex offender policies. It first outlines wardens' observations regarding sex offenders as prison inmates, sex offender survival strategies, and prison-based sex offender treatment programs. Next, perceptions of sex offender registration and notification (SORN) and sex offender residency restrictions are identified. Assessments by wardens about how to best conduct sex offender community notification and what should be reported on a registrant's sex offender registry page are also described. Finally, perspectives regarding the restriction of sex offenders from popular child congregation locations and those measured by the CATSO scale are reported.

\section{Factor Analysis}

Next, the analysis follows previous studies (Conley et al., 2011; Tewksbury \& Mustaine, 2011; Tewksbury et al., in press) by examining whether or not the CATSO scale is an efficient method of data reduction for studying the attitudes and beliefs of prison wardens. Specifically, principle components factor analysis is utilized to evaluate the conceptual integrity of the 18 -item, four factor scale. Initially, wardens' responses to the CATSO scale statements are analyzed with an open-ended number of possible 
components, in order to assess whether or not the views of wardens are the same as those of university students. Based on this outcome, wardens' responses to the CATSO scale statements are subsequently analyzed by allowing no more than five factors to be constructed. The substance of these five factors is then examined for conceptual integrity.

\section{Logistic Regression}

Lastly, the analysis considers the potential sources of prison wardens' perceptions about sex offenders and sex offender policies. In particular, the impact of demographic, experiential, and political influences on their attitudes and beliefs about the fairness of community notification laws, the effectiveness of community notification, and sex offender recidivism are examined. As noted, responses to some of these items are skewed, and there is a relative lack of variation across original answer choices. For this reason, the three dependent variables (i.e., perceived fairness of community notification, perceived effectiveness of community notification, and perceived sex offender recidivism) are dichotomized, and binary logistic regression is utilized. 


\section{CHAPTER III}

\section{FINDINGS}

This chapter reports prison wardens' attitudes and beliefs regarding sex offenders, while focusing on observations of sex offenders as prison inmates and registrants in the community. Specifically, it details both bivariate and multivariate findings from the survey responses of wardens. First, bivariate findings include views about sex offenders as inmates, perceived sex offender survival strategies, and attitudes toward prison-based sex offender treatment programs. Perceptions of sex offender registration and notification (SORN) and sex offender residency restrictions are also described. Such findings continue with assessments about how wardens believe it best to conduct sex offender community notification and what should be reported on a registrant's sex offender registry page. In addition, perspectives regarding the restriction of sex offenders from popular child congregation locations and those measured by the Community Attitudes Toward Sex Offenders (CATSO) scale (Church et al., 2008) are outlined. Second, multivariate findings consider whether or not the CATSO scale is an efficient method of data reduction for studying the attitudes and beliefs of wardens. Such findings also examine the influences on wardens' attitudes and beliefs about the fairness of community notification laws, the effectiveness of community notification, and sex offender recidivism.

\section{Bivariate Findings}

Sex Offenders as Prison Inmates 
Table 2 presents prison wardens' perceptions of sex offenders as prison inmates. Generally, these findings show that sex offenders behind bars are recognized as the most marginalized inmates; however, these correctional clients are not necessarily seen as problematic for institutional management. Specifically, nearly all wardens (98.5\%) believe that most inmates consider sex offenses involving children to be appalling conduct. Perhaps this explains why a majority $(76.1 \%)$ believe that sex offenders are at the bottom of the prison inmate hierarchy. Although a greater proportion (70.2\%) agrees that incarcerated sex offenders are routinely subjected to hostility from other inmates, less than one-half (43.3\%) feel that incarcerated sex offenders are routinely subjected to physical attacks from other inmates. Indeed, when sex offenders arrive in prison, nearly all prison administrators (97.1\%) do not consider them to be in life-threatening danger. In fact, most prison wardens (86.6\%) affirm that their jurisdiction actively protects incarcerated sex offenders from inmate violence. This may provide a rationale for the finding that a majority $(80.6 \%)$ does not believe that it is important to house sex offenders in separate institutions or housing units designated specifically for such inmates. Still, more than one-half (59.7\%) feel that sex offenders are not as safe in prison as inmates convicted of other crimes. Because of their vulnerability in prison, a greater proportion $(52.3 \%)$ believes that sex offenders pose unique challenges for institutional management. Likewise, as a result of their unpredictable behavior in society, a slightly smaller proportion (41.7\%) feels that sex offenders pose unique challenges for institutional management. 
Table 2

Prison Wardens' Perceptions of Sex Offenders as Prison Inmates

\begin{tabular}{|c|c|c|c|c|}
\hline Question & $\begin{array}{l}\text { Strongly } \\
\text { Agree }\end{array}$ & Agree & Disagree & $\begin{array}{l}\text { Strongly } \\
\text { Disagree }\end{array}$ \\
\hline $\begin{array}{l}\text { Most inmates consider sex offenses } \\
\text { involving children to be appalling conduct. }\end{array}$ & $\begin{array}{l}59.7 \% \\
\mathrm{n}=40\end{array}$ & $\begin{array}{l}38.8 \% \\
\mathrm{n}=26\end{array}$ & $\begin{array}{l}1.5 \% \\
\mathrm{n}=1\end{array}$ & $\begin{array}{l}0.0 \% \\
\mathrm{n}=0\end{array}$ \\
\hline $\begin{array}{l}\text { Sex offenders are at the bottom of the } \\
\text { prison inmate hierarchy. }\end{array}$ & $\begin{array}{l}23.9 \% \\
\mathrm{n}=16\end{array}$ & $\begin{array}{l}52.2 \% \\
\mathrm{n}=35\end{array}$ & $\begin{array}{l}20.9 \% \\
\mathrm{n}=14\end{array}$ & $\begin{array}{l}3.0 \% \\
n=2\end{array}$ \\
\hline $\begin{array}{l}\text { Incarcerated sex offenders are routinely } \\
\text { subjected to hostility from other inmates. }\end{array}$ & $\begin{array}{l}6.0 \% \\
n=4\end{array}$ & $\begin{array}{l}64.2 \% \\
n=43\end{array}$ & $\begin{array}{l}28.4 \% \\
\mathrm{n}=19\end{array}$ & $\begin{array}{l}1.5 \% \\
\mathrm{n}=1\end{array}$ \\
\hline $\begin{array}{l}\text { Incarcerated sex offenders are routinely } \\
\text { subjected to physical attacks from other } \\
\text { inmates. }\end{array}$ & $\begin{array}{l}3.0 \% \\
\mathrm{n}=2\end{array}$ & $\begin{array}{l}40.3 \% \\
\mathrm{n}=27\end{array}$ & $\begin{array}{l}49.3 \% \\
\mathrm{n}=33\end{array}$ & $\begin{array}{l}7.5 \% \\
\mathrm{n}=5\end{array}$ \\
\hline $\begin{array}{l}\text { When sex offenders arrive in prison, they } \\
\text { are in immediate life-threatening danger. }\end{array}$ & $\begin{array}{l}1.5 \% \\
\mathrm{n}=1\end{array}$ & $\begin{array}{l}1.5 \% \\
\mathrm{n}=1\end{array}$ & $\begin{array}{l}67.2 \% \\
\mathrm{n}=45\end{array}$ & $\begin{array}{l}29.9 \% \\
\mathrm{n}=20\end{array}$ \\
\hline $\begin{array}{l}\text { My jurisdiction actively protects } \\
\text { incarcerated sex offenders from inmate } \\
\text { violence. }\end{array}$ & $\begin{array}{l}26.9 \% \\
\mathrm{n}=18\end{array}$ & $\begin{array}{l}59.7 \% \\
\mathrm{n}=40\end{array}$ & $\begin{array}{l}10.4 \% \\
\mathrm{n}=7\end{array}$ & $\begin{array}{l}3.0 \% \\
\mathrm{n}=2\end{array}$ \\
\hline $\begin{array}{l}\text { In order to ensure their safety, it is } \\
\text { important to house sex offenders in separate } \\
\text { institutions or housing units designated } \\
\text { specifically for such inmates. }\end{array}$ & $\begin{array}{l}6.0 \% \\
\mathrm{n}=4\end{array}$ & $\begin{array}{c}13.4 \% \\
\mathrm{n}=9\end{array}$ & $\begin{array}{c}53.7 \\
\mathrm{n}=36\end{array}$ & $\begin{array}{l}26.9 \% \\
\mathrm{n}=18\end{array}$ \\
\hline $\begin{array}{l}\text { Sex offenders are not as safe in prison as } \\
\text { inmates convicted of other crimes. }\end{array}$ & $\begin{array}{l}6.0 \% \\
\mathrm{n}=4\end{array}$ & $\begin{array}{l}53.7 \% \\
\mathrm{n}=36\end{array}$ & $\begin{array}{l}37.3 \% \\
n=25\end{array}$ & $\begin{array}{l}3.0 \% \\
n=2\end{array}$ \\
\hline $\begin{array}{l}\text { Because of their vulnerability in prison, sex } \\
\text { offenders pose unique challenges for } \\
\text { institutional management. }\end{array}$ & $\begin{array}{l}7.5 \% \\
n=5\end{array}$ & $\begin{array}{l}44.8 \% \\
\mathrm{n}=30\end{array}$ & $\begin{array}{l}41.8 \% \\
n=28\end{array}$ & $\begin{array}{l}6.0 \% \\
n=4\end{array}$ \\
\hline $\begin{array}{l}\text { Because of their unpredictable behavior in } \\
\text { society, sex offenders pose unique } \\
\text { challenges for institutional management. }\end{array}$ & $\begin{array}{c}10.4 \% \\
n=7\end{array}$ & $\begin{array}{l}31.3 \% \\
\mathrm{n}=21\end{array}$ & $\begin{array}{l}49.3 \% \\
n=33\end{array}$ & $\begin{array}{l}9.0 \% \\
n=6\end{array}$ \\
\hline
\end{tabular}




\section{Sex Offender Survival Strategies}

Table 3 shows prison wardens' attitudes and beliefs regarding sex offender survival strategies that such inmates may adopt during their incarceration. Interestingly, in order to protect themselves from a high risk of inmate violence directed toward sex offenders, most wardens (91.1\%) feel that sex offenders should not disclose their offenses to other inmates. And yet, only a few (16.4\%) believe that incarcerated sex offenders should consider living in protective custody, in order to protect themselves from such a risk.

\section{Table 3}

Prison Wardens' Attitudes and Beliefs Regarding Sex Offender Survival Strategies

\begin{tabular}{lcccc}
\hline Question & $\begin{array}{c}\text { Strongly } \\
\text { Agree }\end{array}$ & Agree & Disagree & $\begin{array}{c}\text { Strongly } \\
\text { Disagree }\end{array}$ \\
\hline $\begin{array}{l}\text { In order to protect themselves from a high } \\
\text { risk of inmate violence directed toward sex } \\
\text { offenders, incarcerated sex offenders should } \\
\text { not disclose their offenses to other inmates. }\end{array}$ & $\begin{array}{c}26.9 \% \\
\mathrm{n}=18\end{array}$ & $\begin{array}{c}64.2 \% \\
\mathrm{n}=43\end{array}$ & $\begin{array}{c}7.5 \% \\
\mathrm{n}=5\end{array}$ & $\begin{array}{l}1.5 \% \\
\mathrm{n}=1\end{array}$ \\
$\begin{array}{l}\text { In order to protect themselves from a high } \\
\text { risk of inmate violence directed toward sex } \\
\text { offenders, incarcerated sex offenders should } \\
\text { consider living in protective custody. }\end{array}$ & $\mathrm{n}=2$ & $\mathrm{n}=9$ & $\mathrm{n}=49$ & $\begin{array}{c}10.4 \% \\
\mathrm{n}=7\end{array}$ \\
\hline
\end{tabular}

\section{Prison-based Sex Offender Treatment Programs}

Table 4 presents prison wardens' attitudes and beliefs regarding institutional sex offender treatment programs. Among wardens, most (83.6\%) feel that changing the behavior of sex offenders is a significant challenge facing correctional administrators. A majority $(71.6 \%)$ believes that their jurisdiction provides effective sex offender treatment programs for incarcerated sex offenders. However, more than one-half $(62.7 \%)$ do not 
believe that sex offender treatment programs are more effective in prison environments than community settings. At the same time, most (84.9\%) feel that sex offender treatment programs should be designed around individual offenders as opposed to being standardized treatment programs.

\section{Table 4}

Prison Wardens' Perceptions of Institutional Sex Offender Treatment Programs

\begin{tabular}{|c|c|c|c|c|}
\hline Question & $\begin{array}{c}\text { Strongly } \\
\text { Agree }\end{array}$ & Agree & Disagree & $\begin{array}{l}\text { Strongly } \\
\text { Disagree }\end{array}$ \\
\hline $\begin{array}{l}\text { Changing the behavior of sex offenders is a } \\
\text { significant challenge facing correctional } \\
\text { administrators. }\end{array}$ & $\begin{array}{l}25.4 \% \\
\mathrm{n}=17\end{array}$ & $\begin{array}{l}58.2 \% \\
\mathrm{n}=39\end{array}$ & $\begin{array}{c}13.4 \% \\
\mathrm{n}=9\end{array}$ & $\begin{array}{l}3.0 \% \\
\mathrm{n}=2\end{array}$ \\
\hline $\begin{array}{l}\text { My jurisdiction provides effective sex } \\
\text { offender treatment programs for } \\
\text { incarcerated sex offenders. }\end{array}$ & $\begin{array}{c}11.9 \% \\
n=8\end{array}$ & $\begin{array}{l}59.7 \% \\
n=40\end{array}$ & $\begin{array}{l}22.4 \% \\
\mathrm{n}=15\end{array}$ & $\begin{array}{l}6.0 \% \\
n=4\end{array}$ \\
\hline $\begin{array}{l}\text { Sex offender treatment programs are more } \\
\text { effective in prison environments than } \\
\text { community settings. }\end{array}$ & $\begin{array}{l}4.5 \% \\
\mathrm{n}=3\end{array}$ & $\begin{array}{l}32.8 \% \\
n=22\end{array}$ & $\begin{array}{l}55.2 \% \\
\mathrm{n}=37\end{array}$ & $\begin{array}{l}7.5 \% \\
\mathrm{n}=5\end{array}$ \\
\hline $\begin{array}{l}\text { Sex offender treatment programs should be } \\
\text { designed around individual offenders as } \\
\text { opposed to being standardized treatment } \\
\text { programs. }\end{array}$ & $\begin{array}{l}19.7 \% \\
\mathrm{n}=13\end{array}$ & $\begin{array}{l}65.2 \% \\
n=43\end{array}$ & $\begin{array}{l}15.2 \% \\
\mathrm{n}=10\end{array}$ & $\begin{array}{l}0.0 \% \\
\mathrm{n}=0\end{array}$ \\
\hline
\end{tabular}

Sex Offender Registration and Notification (SORN) and Residency Restrictions

Table 5 shows prison wardens' attitudes and beliefs regarding SORN and residency restrictions. A large proportion believes that both laws mandating sex offender registration and community notification (75.0\%) and residency restrictions (61.7\%) are effective in preventing sexual victimization. And yet, a majority does not feel that placement on a publicly available sex offender registry deters sex offenders (76.1\%) or general members of the community $(67.7 \%)$ from offending. Interestingly, 
just less than one-half (42.7\%) report that they would still support sex offender residency restrictions, without scientific evidence that such laws are effective in preventing victimization.

Table 5

Prison Wardens' Attitudes and Beliefs Regarding SORN and Residency Restrictions

\begin{tabular}{|c|c|c|c|c|}
\hline Question & $\begin{array}{c}\text { Strongly } \\
\text { Agree }\end{array}$ & Agree & Disagree & $\begin{array}{l}\text { Strongly } \\
\text { Disagree } \\
\end{array}$ \\
\hline $\begin{array}{l}\text { I believe that sex offender registration and } \\
\text { notification is effective in preventing sexual } \\
\text { victimization. }\end{array}$ & $\begin{array}{l}5.9 \% \\
\mathrm{n}=4\end{array}$ & $\begin{array}{l}69.1 \% \\
n=47\end{array}$ & $\begin{array}{l}23.5 \% \\
\mathrm{n}=16\end{array}$ & $\begin{array}{l}1.5 \% \\
n=1\end{array}$ \\
\hline $\begin{array}{l}\text { Laws that prevent sex offenders from living } \\
\text { near schools, parks, or playgrounds are } \\
\text { effective in preventing sexual victimization. }\end{array}$ & $\begin{array}{l}2.9 \% \\
\mathrm{n}=2\end{array}$ & $\begin{array}{l}58.8 \% \\
\mathrm{n}=40\end{array}$ & $\begin{array}{l}32.4 \% \\
n=22\end{array}$ & $\begin{array}{l}5.9 \% \\
n=4\end{array}$ \\
\hline $\begin{array}{l}\text { Sex offenders are deterred from sex } \\
\text { offending because of being listed on a } \\
\text { publicly available sex offender registry. }\end{array}$ & $\begin{array}{l}0.0 \% \\
\mathrm{n}=0\end{array}$ & $\begin{array}{l}23.9 \% \\
\mathrm{n}=16\end{array}$ & $\begin{array}{l}65.7 \% \\
\mathrm{n}=44\end{array}$ & $\begin{array}{c}10.4 \% \\
\mathrm{n}=7\end{array}$ \\
\hline $\begin{array}{l}\text { General members of the community are } \\
\text { deterred from sex offending because they do } \\
\text { not want the humiliation of being listed on a } \\
\text { publicly available sex offender registry. }\end{array}$ & $\begin{array}{l}2.9 \% \\
n=2\end{array}$ & $\begin{array}{l}29.4 \% \\
\mathrm{n}=20\end{array}$ & $\begin{array}{l}55.9 \% \\
\mathrm{n}=38\end{array}$ & $\begin{array}{c}11.8 \% \\
\mathrm{n}=8\end{array}$ \\
\hline $\begin{array}{l}\text { I would support sex offender housing } \\
\text { restriction laws even if there is no scientific } \\
\text { evidence that they are effective in } \\
\text { preventing victimization. }\end{array}$ & $\begin{array}{c}10.3 \% \\
\mathrm{n}=7\end{array}$ & $\begin{array}{l}32.4 \% \\
\mathrm{n}=22\end{array}$ & $\begin{array}{l}42.6 \% \\
n=29\end{array}$ & $\begin{array}{l}14.7 \% \\
n=10\end{array}$ \\
\hline
\end{tabular}

How to Best Conduct Sex Offender Community Notification

Table 6 presents the proportions of prison wardens who support various community notification methods. Two methods, registration lists on the Internet $(79.4 \%)$ and at law enforcement agencies (77.9\%), are the most commonly endorsed. Media releases/announcements $(33.8 \%)$, mailed or posted flyers $(25.0 \%)$, and automated 
telephone calls to residents (20.6\%) as means of community notification are supported by a significantly smaller proportion, and only a minority, of wardens. Even fewer (17.6\%) endorse information dissemination by the police only upon request. The least commonly supported methods are door-to-door information from the police/sheriff $(10.3 \%)$ and community meetings $(10.3 \%)$.

\section{Table 6}

Prison Wardens' Perceptions Regarding How to Best Conduct Community Notification

Notification Method Percentage (Number) Supporting Notification Method

Registration lists on the Internet $79.4 \%(\mathrm{n}=54)$

Registration lists at law enforcement agencies

$77.9 \%(\mathrm{n}=53)$

Media releases/announcements

$33.8 \%(\mathrm{n}=23)$

Mailed or posted flyers

$25.0 \%(\mathrm{n}=17)$

Automated telephone calls to residents

$20.6 \%(n=14)$

Information provided by police only upon request

$17.6 \%(\mathrm{n}=12)$

Door-to-door information from the police/sheriff

$10.3 \%(\mathrm{n}=7)$

Community meetings

$10.3 \%(n=7)$

What Should Be Reported on a Registrant's Sex Offender Registry Page

Table 7 shows prison wardens' attitudes and beliefs regarding what should be reported on a registrant's sex offender registry page. Three items, name (94.1\%), photograph (94.1\%), and home address $(80.9 \%)$, are viewed by most wardens as appropriate items that should be incorporated. However, it is notable that, even for these foundational pieces of information, there is not unanimity. $5.9 \%$ do not believe even a 
registrant's name should be listed on such a registry. This may correspond with the fact that about one-third (36.8\%) believe only those sex offenders with high risk assessment scores should be subject to community notification.

Just less than one-half feel that vehicle (45.6\%) and offense (42.6\%) descriptions should be reported on a registrant's sex offender registry page. Approximately only onethird (36.8\%) see a registrant's vehicle license plate number as necessary for inclusion. A registrant's work location/address (29.4\%) and with whom he or she lives (23.5\%) are considered much less critical. A small proportion believes a registrant's HIV/STD test results (17.6\%), fingerprints $(10.3 \%)$, and home telephone number $(7.4 \%)$ are viable items for inclusion. Interestingly, the age (22.1\%), gender (17.6\%), and name $(8.8 \%)$ of victims are also viewed by some wardens, although it is a distinct minority, as suitable items for incorporation into a registrant's sex offender registry page.

\section{Table 7}

What Should Be Reported on a Registrant's Sex Offender Registry Page

Name

$$
94.1 \%(n=64)
$$

Photograph

$$
94.1 \%(\mathrm{n}=64)
$$

Home Address

$$
80.9 \%(n=55)
$$

Vehicle description

Description of offense(s)

Vehicle license plate number

Work location/address

$$
29.4 \%(\mathrm{n}=20)
$$

With whom the sex offender lives

$$
23.5 \%(n=16)
$$


Victim(s) age(s)

Victim(s) gender(s)

HIV and STD test results for the sex offender

Fingerprints

Victim(s) name(s)

Home telephone number
$22.1 \%(\mathrm{n}=15)$

$17.6 \%(n=12)$

$17.6 \%(n=12)$

$10.3 \%(n=7)$

$8.8 \%(n=6)$

$7.4 \%(n=5)$

Restricting Sex Offenders from Popular Child Congregation Locations

Table 8 presents prison wardens' attitudes and beliefs about the appropriateness of restricting sex offenders from living near specific child congregation locations. Two sites, schools (91.2\%) and daycares (91.2\%), are the types of locations most frequently viewed by wardens as appropriate locations from which to prohibit sex offenders from living near. A majority believes that sex offenders should be restricted from living near youth athletic fields (70.6\%), skateboard parks (66.2\%), public parks (64.7\%), and school bus stops (63.2\%). In addition, more than one-half (55.9\%) endorse precluding sex offenders from living close to public swimming pools. Fewer wardens consider public libraries (23.5\%) and public restrooms (17.6\%) to be appropriate locations, and fast food restaurants $(4.4 \%)$ are seen as the least suitable locations from which to restrict sex offenders from living near.

\section{Table 8}

Restricting Sex Offenders from Popular Child Congregation Locations

Location

Schools
Percentage (Number)

Supporting Location Restriction

$91.2 \%(\mathrm{n}=62)$ 
Youth athletic fields

Skateboard parks

Public parks

School bus stops

$63.2 \%(n=43)$

Public swimming pools

$55.9 \%(n=38)$

Public libraries

$23.5 \%(n=16)$

Public restrooms

$17.6 \%(n=12)$

Fast food restaurants

$4.4 \%(n=3)$

18 CATSO Scale Items

Table 9 shows prison wardens' attitudes and beliefs regarding sex offenders measured using Church et al.'s (2008) original Community Attitudes Toward Sex Offenders (CATSO) scale. As discussed above, the CATSO scale, as originally formulated, consists of four components: Social Isolation, Capacity to Change, Severity/Dangerousness, and Deviancy. Results from the Social Isolation component are first outlined. Wardens largely do not associate sex offenders with inherent social isolation. Very few believe that sex offenders prefer to stay home alone rather than be around lots of people (18.0\%) and feel that sex offenders have difficulty making friends even if they try real hard (10.3\%). Likewise, a large proportion does not believe that most sex offenders keep to themselves (80.9\%), are unmarried men (86.4\%), and do not have close friends $(85.2 \%)$.

Next, regarding the Capacity to Change component, it is seen that wardens generally consider sex offenders to be capable of change. A majority $(67.2 \%)$ believes 
that sex offenders can learn to change their behavior with support and therapy, and only a small proportion (16.2\%) feels that trying to rehabilitate a sex offender is a waste of time. Only $7.4 \%$ believe that convicted sex offenders should never be released from prison. And yet, more than one-half (55.9\%) feel that sex offenders should wear tracking devices so their location can be pinpointed at any time. Similarly, more than one-third (40.3\%) believe that sex offenders should lose their civil rights.

Third, for the Severity/Dangerousness component, responses generally show that sex offenders are viewed as serious criminals who are especially dangerous. Nearly all do not consider sex offenders who use emotional control to be less serious than sex offenders who use physical control $(95.6 \%)$, do not perceive sex offenses against known victims to be less serious than sex offenses against strangers (97.1\%), and do not feel that male sex offenders should be punished more severely than female sex offenders (94.1\%). Similarly, a large majority ( $85.3 \%)$ does not believe the prison sentences that sex offenders receive are much too long when compared to the sentence durations for other crimes. And, only about one-quarter (27.9\%) feel that only a few sex offenders are dangerous.

Fourth, responses to the Deviancy component show that wardens generally do not consider sex offenders to be more deviant or sexually preoccupied than other individuals. Few $(10.5 \%)$ report that they believe sex offenders want to have sex more often than the average person, and only one-fifth (19.4\%) feel that sex offenders in fact do have high rates of sexual activity. Somewhat interestingly, one in four wardens $(25.0 \%)$ see sexual fondling as less serious than rape. 


\section{Table 9}

Prison Wardens' Attitudes and Beliefs Regarding the 18 CATSO Items

Question

Sex offenders prefer to stay home alone rather than be around lots of people.

\section{Strongly}

Agree

$\begin{array}{cccc}0.0 \% & 17.9 \% & 71.6 \% & 10.4 \% \\ \mathrm{n}=0 & \mathrm{n}=12 & \mathrm{n}=48 & \mathrm{n}=7 \\ & & & \\ 0.0 \% & 10.3 \% & 76.5 \% & 13.2 \% \\ \mathrm{n}=0 & \mathrm{n}=7 & \mathrm{n}=52 & \mathrm{n}=9\end{array}$

Most sex offenders keep to themselves.

Most sex offenders are unmarried men.

Most sex offenders do not have close friends.

With support and therapy, someone who committed a sex offense can learn to change their behavior.

Trying to rehabilitate a sex offender is a waste of time.

Convicted sex offenders should never be released from prison.

Sex offenders should wear tracking devices so their location can be pinpointed at any time.

People who commit sex offenses should lose their civil rights (e.g., voting, privacy, etc.).

Someone who uses emotional control when committing a sex offense is not as bad as someone who uses physical control when committing a sex offense.

A sex offense committed against someone the perpetrator knows is less serious than a sex offense committed against a stranger.

$\begin{array}{llll}1.5 \% & 17.6 \% & 72.1 \% & 8.8 \% \\ \mathrm{n}=1 & \mathrm{n}=12 & \mathrm{n}=49 & \mathrm{n}=6\end{array}$

$\begin{array}{cccc}0.0 \% & 13.6 \% & 69.7 \% & 16.7 \% \\ \mathrm{n}=0 & \mathrm{n}=9 & \mathrm{n}=46 & \mathrm{n}=11\end{array}$

$\begin{array}{llll}0.0 \% & 14.7 \% & 67.6 \% & 17.6 \% \\ \mathrm{n}=0 & \mathrm{n}=10 & \mathrm{n}=46 & \mathrm{n}=12 \\ & & & \\ 4.5 \% & 62.7 \% & 29.9 \% & 3.0 \% \\ \mathrm{n}=3 & \mathrm{n}=42 & \mathrm{n}=20 & \mathrm{n}=2\end{array}$

$0.0 \% \quad 16.2 \% \quad 72.1 \% \quad 11.8 \%$

$\mathrm{n}=0 \quad \mathrm{n}=11 \quad \mathrm{n}=49 \quad \mathrm{n}=8$

$\begin{array}{cccc}1.5 \% & 5.9 \% & 79.4 \% & 13.2 \% \\ \mathrm{n}=1 & \mathrm{n}=4 & \mathrm{n}=54 & \mathrm{n}=9\end{array}$

$10.3 \% \quad 45.6 \% \quad 44.1 \% \quad 0.0 \%$

$\mathrm{n}=7 \quad \mathrm{n}=31 \quad \mathrm{n}=30 \quad \mathrm{n}=0$

$7.5 \% \quad 32.8 \% \quad 56.7 \% \quad 3.0 \%$

$\mathrm{n}=5 \quad \mathrm{n}=22 \quad \mathrm{n}=38 \quad \mathrm{n}=2$

$\begin{array}{llll}1.5 \% & 2.9 \% & 61.8 \% & 33.8 \% \\ \mathrm{n}=1 & \mathrm{n}=2 & \mathrm{n}=42 & \mathrm{n}=23\end{array}$

$\begin{array}{llll}1.5 \% & 1.5 \% & 55.9 \% & 41.2 \% \\ \mathrm{n}=1 & \mathrm{n}=1 & \mathrm{n}=38 & \mathrm{n}=28\end{array}$ 
Male sex offenders should be punished more severely than female sex offenders.

The prison sentences sex offenders receive are much too long when compared to the sentence lengths for other crimes.

Only a few sex offenders are dangerous.

People who commit sex offenses want to have sex more often than the average person.

Sexual fondling (inappropriate, unwarranted touch) is not as bad as rape.

Sex offenders have high rates of sexual activity.

$$
\begin{array}{llll}
2.9 \% & 2.9 \% & 69.1 \% & 25.0 \% \\
\mathrm{n}=2 & \mathrm{n}=2 & \mathrm{n}=47 & \mathrm{n}=17
\end{array}
$$

$2.9 \% \quad 11.8 \% \quad 64.7 \% \quad 20.6 \%$

$\mathrm{n}=2 \quad \mathrm{n}=8 \quad \mathrm{n}=44 \quad \mathrm{n}=14$

$\begin{array}{llll}2.9 \% & 25.0 \% & 57.4 \% & 14.7 \% \\ \mathrm{n}=2 & \mathrm{n}=17 & \mathrm{n}=39 & \mathrm{n}=10\end{array}$

$1.5 \% \quad 9.0 \% \quad 77.6 \% \quad 11.9 \%$

$\begin{array}{llll}\mathrm{n}=1 & \mathrm{n}=6 & \mathrm{n}=52 & \mathrm{n}=8\end{array}$

$2.9 \% \quad 22.1 \% \quad 50.0 \% \quad 25.0 \%$

$\mathrm{n}=2 \quad \mathrm{n}=15 \quad \mathrm{n}=34 \quad \mathrm{n}=17$

$3.0 \% \quad 16.4 \% \quad 79.1 \% \quad 1.5 \%$

$\mathrm{n}=2 \quad \mathrm{n}=11 \quad \mathrm{n}=53 \quad \mathrm{n}=1$

\section{Multivariate Findings}

CATSO Scale as an Efficient Method of Data Reduction

Whether or not the CATSO survey items are efficient as a method of data

reduction for a large number of attitudinal measures regarding sex offenders and sex

offender policies is examined, following previous attempts to show its utility with parole

board members (Tewksbury \& Mustaine, 2011) and community corrections professionals

(Conley et al., 2011; Tewksbury et al., in press). As originally formulated, Church et al.

(2008) showed through factor analysis that four components (Social Isolation, Capacity

to Change, Severity/Dangerousness, and Deviancy) emerged in the perceptions of

university students toward sex offenders. The present research initially analyzes the data

with an open-ended number of possible components, in order to assess whether or not the views of prison wardens are the same as those of university students. Results suggest that these two populations' views congregate differently. 
The first factor analysis, which allows for an open-ended number of factors to emerge, reveals six components that emerge from the 18 scale items. However, only the first five of these six components contribute significantly to understanding the data more effectively. None of the 18 scale items load primarily on the sixth component, which indicates that five components may be appropriate. According to the scree plot of factors, after the fifth component emerged, the sixth component did not contribute significantly to the data variance.

Subsequently, when the factor analysis is restricted to allowing no more than five factors to be constructed, results show that five components emerge from the 18 scale items. In this solution, six items load on both the first component (with factor loading scores ranging from 0.63 to 0.88 ) and the second component (with factor loading scores ranging from 0.45 to 0.69 ). Two items load on each of the third component (with factor loading scores ranging from 0.70 to 0.71 ), the fourth component (with factor loading scores both at 0.57 ), and the fifth component (with factor loading scores both at 0.53 ).

As can be seen in Table 10, examination of these components, which focuses on conceptual integrity, suggests that the established components are problematic. On component number one, one item (i.e., "Male sex offenders should be punished more severely than female sex offenders") does not correspond conceptually with the other items contained within the first component. Similarly, two items (i.e., "Someone who uses emotional control when committing a sex offense is not as bad as someone who uses physical control when committing a sex offense" and "A sex offense committed against someone the perpetrator knows is less serious than a sex offense committed against a stranger") do not match conceptually with the other items contained within the second 
component, and the two items contained within the fourth component (i.e., "Sexual fondling is not as bad as rape" and "Trying to rehabilitate a sex offender is a waste of time") fail to exhibit clear and obvious conceptual sense together. Such factorial results indicate that the substance of these factors falls short of successfully measuring attitudes among prison wardens. As a result, it is concluded that the CATSO scale does not provide a meaningful or efficient means of examining and understanding the views of prison wardens regarding sex offenders and sex offender policies.

\section{Table 10}

Five-Component Factor Analysis of CATSO Survey Items

\begin{tabular}{rr}
\hline Item & Factor \\
& Loading \\
& Score \\
\hline
\end{tabular}

Factor 1

Male sex offenders should be punished more severely than female sex offenders.

Sex offenders prefer to stay home alone rather than be around lots of people.

Most sex offenders do not have close friends.

Sex offenders have difficulty making friends even if they try real hard.

Most sex offenders are unmarried men.

Most sex offenders keep to themselves.

Factor 2

With support and therapy, someone who committed a sex offense can learn to change their behavior.

People who commit sex offenses should lose their civil rights (e.g., voting, privacy, etc.). 
Sex offenders should wear tracking devices so their location can be pinpointed at any time.

Someone who uses emotional control when committing a sex offense is not as bad as someone who uses physical control when committing a sex offense.

A sex offense committed against someone the perpetrator knows is less serious than a sex offense committed against a stranger.

Convicted sex offenders should never be released from prison.

Factor 3

People who commit sex offenses want to have sex more often than the average person.

Sex offenders have high rates of sexual activity.

Factor 4

Sexual fondling (inappropriate, unwarranted touch) is not as bad as rape.

Trying to rehabilitate a sex offender is a waste of time.

Factor 5

The prison sentences sex offenders receive are much too long when compared to the sentence lengths for other crimes.

Only a few sex offenders are dangerous.

Influences on Prison Wardens' Attitudes and Beliefs

A number of factors (i.e., demographic, experiential, and political) that may impact the attitudes and beliefs of prison wardens about sex offender policies are now examined, in order to potentially explain consistencies and variations in perspectives. Specifically, this final section considers wardens' perceptions regarding the fairness of community notification, the effectiveness of community notification, the prevalence of sex offender recidivism, and whether or not and how demographic, experiential, and 
political variables are associated with differences in perceptions. Results from three separate logistic regression analyses indicate that none of the models provide a statistically significant understanding of the sources for wardens' attitudes and beliefs.

Table 11 presents the results for the equation assessing the likelihood of prison wardens believing that sex offender notification laws in their community are fair. However, this equation is not statistically significant $(\alpha=0.54)$. This suggests that such demographic, experiential, and political influences may not be especially acute for determining wardens' views of the fairness of community notification laws.

\section{Table 11}

Influences on Prison Wardens' Views of the Fairness of Community Notification Laws ${ }^{2}$

\begin{tabular}{lcccc}
\hline Variable & B & SE & $\operatorname{Exp}(\mathrm{B})$ & Tolerance \\
\hline Sex & -0.55 & 1.28 & 0.57 & 0.793 \\
Race & 1.36 & 1.35 & 3.91 & 0.868 \\
Age & 0.03 & 0.07 & 1.03 & 0.691 \\
Number of Children & -0.46 & 0.31 & 0.62 & 0.811 \\
Educational Achievement & -0.88 & 0.61 & 0.41 & 0.832 \\
Tenure as Prison Warden in Years & 0.05 & 0.07 & 1.05 & 0.715 \\
Political Orientation & 0.20 & 0.42 & 1.23 & 0.791 \\
Constant & 4.55 & 5.00 & & \\
\hline
\end{tabular}

Note: All variables in the model are not significant at $\mathrm{p} \leq 0.10$.

$\mathrm{x}^{2}=5.952 ; \alpha=0.54$

$\mathrm{df}=7$

Nagelkerke $\mathrm{R}^{2}=0.16$

\footnotetext{
${ }^{2}$ Marital Status was removed from this model because it significantly skewed the data.
} 
Table 12 shows results for the equation assessing the likelihood of prison wardens believing that community notification is an effective way to reduce the number of sex offenses. However, this equation is also not statistically significant $(\alpha=0.32)$. This suggests that such demographic, experiential, and political influences may not be especially acute for determining wardens' views of the effectiveness of community notification laws.

Table 12

Influences on Prison Wardens' Views of the Effectiveness of Community Notification $\underline{\text { Laws }}$

\begin{tabular}{lcccc}
\hline Variable & B & SE & $\operatorname{Exp}(\mathrm{B})$ & Tolerance \\
\hline Sex & 0.12 & 0.89 & 1.13 & 0.778 \\
Race & 1.36 & 0.82 & 3.89 & 0.724 \\
Age & -0.04 & 0.05 & 0.95 & 0.674 \\
Marital Status & 1.33 & 0.94 & 3.76 & 0.809 \\
Number of Children & 0.18 & 0.22 & 1.20 & 0.790 \\
Educational Achievement & 0.00 & 0.36 & 1.00 & 0.831 \\
Tenure as Prison Warden in Years & -0.02 & 0.04 & 0.97 & 0.713 \\
Political Orientation & 0.51 & 0.28 & 1.68 & 0.767 \\
Constant & -2.12 & 3.61 & & \\
\hline
\end{tabular}

Note: All variables in the model are not significant at $p \leq 0.10$.

$\mathrm{x}^{2}=9.229 ; \alpha=0.32$

$\mathrm{df}=8$

Nagelkerke $\mathrm{R}^{2}=0.18$ 
The final logistic regression model (Table 13) presents the results for the equation assessing the likelihood of prison wardens believing that sex offenders recidivate at a much higher/higher rate than other criminals. However, this equation is also not statistically significant $(\alpha=0.15)$. This suggests that such demographic, experiential, and political influences may not be especially acute for determining wardens' views of sex offender recidivism.

Table 13

Influences on Prison Wardens' Views of Sex Offender Recidivism

\begin{tabular}{lcccc}
\hline Variable & B & SE & Exp (B) & Tolerance \\
\hline Sex & -0.47 & 1.13 & 0.62 & 0.778 \\
Race & -0.78 & 0.99 & 0.45 & 0.724 \\
Age & 0.11 & 0.07 & 1.12 & 0.674 \\
Marital Status & -0.77 & 1.15 & 0.46 & 0.809 \\
Number of Children & -0.10 & 0.33 & 0.90 & 0.790 \\
Educational Achievement & -0.64 & 0.54 & 0.52 & 0.831 \\
Tenure as Prison Warden in Years & -0.05 & 0.06 & 0.94 & 0.713 \\
Political Orientation & 0.76 & 0.37 & 2.13 & 0.767 \\
Constant & -3.43 & 5.29 & & \\
\hline
\end{tabular}

Note: All variables in the model are not significant at $p \leq 0.10$.

$\mathrm{x}^{2}=11.950 ; \alpha=0.15$

$\mathrm{df}=8$

Nagelkerke $\mathrm{R}^{2}=0.32$

\section{Summary}

Sex offenders behind bars are generally recognized by this sample of prison wardens as the most marginalized inmates; however, these correctional clients are not 
necessarily seen as problematic for institutional management. Although prison violence aimed at sex offenders is acknowledged, prison wardens do not automatically perceive incarcerated sex offenders as inevitable victims of physical violence. Wardens believe sex offenders in prison should not disclose their offenses to other inmates, and they see institutional sex offender treatment programs as critical tools for rehabilitation.

Both SORN and residency restrictions are generally considered to be effective in preventing sexual victimization. However, at the same time, prison wardens do not see placement on a publicly available sex offender registry as an effective (specific or general) deterrent. A significant minority indicates that they would still support sex offender residency restrictions without scientific evidence that such laws are effective in preventing victimization.

Among prison wardens, Internet-based sex offender registration lists are the most commonly endorsed methods of community notification. A registrant's name, photograph, and home address are seen as the most suitable items that should be incorporated on a sex offender registry page. Wardens also generally endorse precluding sex offenders from living close to schools, daycares, youth athletic fields, skateboard parks, public parks, schools bus stops, and public swimming pools.

Prison wardens generally do not associate sex offenders with inherent social isolation. Although sex offenders are viewed as capable of changing their criminal behavior, they are viewed as serious criminals who are especially dangerous. Sex offenders are also not considered to be more deviant or sexually preoccupied than other individuals. 
The CATSO scale is not an efficient method of data reduction for studying the attitudes and beliefs of prison wardens, despite Church et al.'s (2008) assertion that the instrument should be efficient and effective at assessing the views of criminal justice actors. The substance of factors constructed by two separate factor analyses fail to successfully measure wardens' perceptions of sex offenders. In addition, results from three separate logistic regression analyses indicate that none of the models (i.e., influences on perceived fairness of community notification laws, influences on perceived effectiveness of community notification laws, and influences on perceived sex offender recidivism) provide a statistically significant understanding of the sources for prison wardens' attitudes and beliefs. Thus, factors beyond demographics, experience, and political views captured in this research may be responsible for impacting the perceptions of wardens regarding sex offender policies. 


\section{CHAPTER IV}

\section{DISCUSSION AND POLICY IMPLICATIONS}

The primary focus of this study was to examine prison wardens' attitudes and beliefs about sex offenders and sex offender policies. By means of descriptive statistics, principle component factor analyses, and logistic regression models, this research attempted to gauge how wardens understand, perceive, and respond to sex offenders and sex offender management. The findings of this study lend support to existing literature about perceptions of sex offenders and sex offender policies, provide insights into wardens' views of sex offenders, and suggest directions for future research.

\section{Analysis and Implications}

Sex Offenders as Prison Inmates

Findings from this study highlight prison wardens' views about sex offenders as prison inmates, perceived sex offender survival strategies, and attitudes toward prisonbased sex offender treatment programs. Wardens generally recognize sex offenders behind bars as the most marginalized inmates; however, these correctional clients are not necessarily seen as problematic for institutional management. Although prison violence aimed at sex offenders is acknowledged, wardens do not automatically perceive incarcerated sex offenders as inevitable victims of physical violence. However, prison wardens, who largely serve administrative roles and are not necessarily exposed to everyday interactions between inmates, may be blinded to the true experience of sex offenders behind bars. For this reason, it is important that wardens solicit, receive, and 
utilize accurate information regarding the safety of sex offenders within their institutions. And, even if physical assaults are not commonly directed at sex offenders, these correctional administrators must recognize that prison violence still exists through threats and hostility.

Wardens should remain cognizant of the fact that sex offenders, as the most marginalized inmates, may experience unique difficulties in prison because of their offenses. It is true that wardens largely believe that sex offenders in prison should not disclose their offenses to other inmates, but more proactive measures from institutional leadership may be necessary. Wardens should make it a point to closely monitor the safety of their clients with sex offense convictions through consultation with their correctional officers.

Wardens also see institutional sex offender treatment programs as critical tools for rehabilitation. Thus, such services should potentially be expanded within correctional institutions, with limited wait time for sex offenders to receive treatment. At the same time, more than one-half of wardens did not believe sex offender treatment programs were more effective in prison environments than community settings. Thus, reasons for why such prison-based treatment curriculums may be less effective need to be considered. Institutional sex offender treatment programs may need to be revamped and remodeled to closely emulate those programs that are successful in the community. Such treatment programs should incorporate ways in which sex offenders can potentially mediate hostility from other inmates and protect themselves from violence. Wardens should work with correctional treatment providers to both prevent and address violence directed toward sex offenders. 
Sex Offender Registration and Notification (SORN) and Residency Restrictions

In this section, prison wardens' attitudes and beliefs regarding SORN and residency restrictions are compared with those of parole board members (Tewksbury \& Mustaine, 2011) and community corrections professionals (Tewksbury et al., 2011). Wardens are more likely to believe that both laws mandating sex offender registration and community notification $(75.0 \%$ in comparison to $61.3 \%$ of parole board members and $59.0 \%$ of community corrections professionals) and residency restrictions $(61.7 \%$ in comparison to $42.3 \%$ of parole board members and $50.4 \%$ of community corrections professionals) are effective in preventing sexual victimization.

And yet, a majority of each population does not feel that placement on a publicly available sex offender registry deters sex offenders ( $76.1 \%$ of wardens, $72.9 \%$ of parole board members, and $81.4 \%$ of community corrections professionals) or general members of the community $(67.7 \%$ of wardens, $74.2 \%$ of parole board members, and $76.1 \%$ of community corrections professionals) from offending. Thus, this lends support to the fact that sex offender registration and accompanying policies do not serve their intended purpose. Criminal justice policies that are viewed as ineffective by those obligated to implement and enforce them warrant closer inspection.

Based on the negative consequences of registration and community notification experienced and perceived by sex offenders (Levenson \& Cotter, 2005a; Levenson, Zgoba, \& Tewksbury, 2007; Tewksbury, 2004, 2005; Tewksbury \& Lees, 2007; Tewksbury \& Mustaine, 2007) and their families (Farkas \& Miller, 2007; Levenson \& Tewksbury, 2009; Tewksbury \& Levenson, 2009), and now three distinct perceptions from populations of criminal justice system actors, the efficacy of such sex offender 
policies needs to be reconsidered. Besides, research has demonstrated that sex offender registration and community notification does not generate significant decreases in sex offenses or increases in public safety (Barnes, Dukes, Tewksbury, \& De Troye, 2009; Duwe, Donnay, \& Tewksbury, 2008; Tewksbury \& Jennings, 2010; Zgoba, Veysey, \& Dalessandro, 2010). Interestingly, however, a significant minority of each population (42.7\% of wardens, $36.6 \%$ of parole board members, and $41.5 \%$ community corrections professionals) report that they would still support sex offender residency restrictions, without scientific evidence that such laws are effective in preventing victimization. It is perhaps this flagrant disregard for empirical evidence expressed by some criminal justice system actors that most closely resembles blatant vengeance.

How to Best Conduct Sex Offender Community Notification

In this section, the proportions of prison wardens who support various community notification methods are compared with those of parole board members (Tewksbury \& Mustaine, 2011) and community corrections professionals (Tewksbury et al., 2011). Only one method, registration lists at law enforcement agencies $(77.9 \%$ of wardens, $71.3 \%$ of parole board members, and $71.7 \%$ of community corrections professionals), is supported by a majority of each population. However, registration lists on the Internet are commonly endorsed by wardens (79.4\%) and community corrections professionals $(84.0 \%)$, but not parole board members $(47.5 \%)$. This may explain why parole board members (46.3\%) are more likely than wardens (17.6\%) and community corrections professionals (13.7\%) to endorse information dissemination by the police only upon request. 
Media releases/announcements (33.8\% of wardens, $27.5 \%$ of parole board members, and $31.6 \%$ of community corrections professionals), mailed or posted flyers ( $25.0 \%$ of wardens, $16.3 \%$ of parole board members, and $32.5 \%$ of community corrections professionals), and automated telephone calls to residents ( $20.6 \%$ of wardens, $12.5 \%$ of parole board members, and $15.5 \%$ of community corrections professionals) as means of community notification are supported by a significantly smaller proportion, and only a minority, of each population. Interestingly, community corrections professionals are more likely to endorse door-to-door information from the police/sheriff ( $24.0 \%$ in comparison to $10.3 \%$ of wardens and $10.0 \%$ of parole board members) and community meetings $(29.2 \%$ in comparison to $10.3 \%$ of wardens and $12.5 \%$ of parole board members). These functions are often involved in the responsibilities and duties performed by community corrections professionals, which may explain their perceived importance among this group.

What Should Be Reported on a Registrant's Sex Offender Registry Page In this section, prison wardens' attitudes and beliefs regarding what should be reported on a registrant's sex offender registry page are compared with those of parole board members (Tewksbury \& Mustaine, 2011) and community corrections professionals (Tewksbury et al., 2011). Three items, name $(94.1 \%$ of wardens, $87.5 \%$ of parole board members, and $94.8 \%$ of community corrections professionals), photograph ( $94.1 \%$ of wardens, $80.0 \%$ of parole board members, and $93.9 \%$ of community corrections professionals), and home address ( $80.9 \%$ of wardens, $66.3 \%$ of parole board members, and $75.1 \%$ of community corrections professionals), are viewed by most of each population as appropriate items that should be incorporated. However, it is notable that, 
even for these foundational pieces of information, there is not unanimity. This calls into question the value of even the most basic forms of community notification. Just less than one-half of wardens (45.6\%) and community corrections professionals (49.3\%), and only one-third (32.5\%) of parole board members, feel that vehicle descriptions should be reported on a registrant's sex offender registry page.

Community corrections professionals $(75.8 \%)$ are more likely than wardens (42.6\%) and parole board members (53.8\%) to believe offense descriptions should be reported on a registrant's sex offender registry page. Approximately only one-third (36.8\% of wardens, $33.8 \%$ of parole board members, and $33.4 \%$ of community corrections professionals) see a registrant's vehicle license plate number as necessary for inclusion. Roughly one-quarter of each population consider a registrant's work location/address ( $29.4 \%$ of wardens, $23.8 \%$ of parole board members, and $25.9 \%$ of community corrections professionals) as important, while about one-fifth of each population consider with whom a registrant lives $(23.5 \%$ of wardens, $15.0 \%$ of parole board members, and $15.9 \%$ of community corrections professionals) as critical.

A small proportion believes a registrant's HIV/STD test results $(17.6 \%$ of wardens, $10.0 \%$ of parole board members, and $13.1 \%$ of community corrections professionals), fingerprints ( $10.3 \%$ of wardens, $7.5 \%$ of parole board members, and $5.5 \%$ of community corrections professionals), and home telephone number ( $7.4 \%$ of wardens, $5.0 \%$ of parole board members, and $3.5 \%$ of community corrections professionals) are viable items for inclusion. Interestingly, community corrections professionals are more likely to view victim age ( $45.3 \%$ in comparison to $22.1 \%$ of wardens and $22.5 \%$ of parole board members) and victim gender (41.9\% in comparison to $17.6 \%$ of wardens and 
$20.0 \%$ of parole board members) as suitable items for incorporation into a registrant's sex offender registry page. Victim name ( $8.8 \%$ of wardens, $2.5 \%$ of parole board members, and $2.2 \%$ of community corrections professionals) is seen as much less critical.

Restricting Sex Offenders from Popular Child Congregation Locations

In this section, prison wardens' attitudes and beliefs about the appropriateness of restricting sex offenders from living near specific child congregation locations are compared with those of parole board members (Tewksbury \& Mustaine, 2011) and community corrections professionals (Tewksbury et al., 2011). Two sites, schools ( $91.2 \%$ of wardens, $66.7 \%$ of parole board members, and $78.1 \%$ of community corrections professionals) and daycares ( $91.2 \%$ of wardens, $60.3 \%$ of parole board members, and $70.7 \%$ of community corrections professionals), are the types of locations most frequently viewed by these populations as appropriate locations from which to prohibit sex offenders from living near. A majority of wardens (70.6\%) and community corrections professionals (63.1\%), and more than one-third of parole board members (41.0\%), believes that sex offenders should be restricted from living near youth athletic fields. This is also true of public parks $(64.7 \%$ of wardens, $39.7 \%$ of parole board members, and $57.7 \%$ of community corrections professionals).

Wardens are more likely to support prohibiting sex offenders from living near skateboard parks ( $66.2 \%$ in comparison to $30.8 \%$ of parole board members and $49.5 \%$ of community corrections professionals) school bus stops (63.2\% in comparison to $34.6 \%$ of parole board members and $49.2 \%$ of community corrections professionals) and public swimming pools $(55.9 \%$ in comparison to $32.1 \%$ of parole board members and $51.4 \%$ of community corrections professionals). A small minority from each population considers 
public libraries ( $23.5 \%$ of wardens, $14.1 \%$ of parole board members, and $19.6 \%$ of community corrections professionals) and public restrooms (17.6\% of wardens, $5.1 \%$ of parole board members, and $16.4 \%$ of community corrections professionals) to be appropriate locations, and fast food restaurants ( $4.4 \%$ of wardens, $0.0 \%$ of parole board members, and $5.8 \%$ of community corrections professionals) are seen by each population as the least suitable locations from which to restrict sex offenders from living near.

Overall, the responses of prison wardens and community corrections professionals are more likely to be aligned with each other than with parole board members. Because wardens and other corrections professionals have more frequent and direct contact with sex offenders, their perceptions of the effectiveness of certain policies are likely to be similar. However, the roles of wardens and community corrections professionals are quite different within the realm of corrections. Most importantly, community corrections professionals must interact with and manage clients in a less-controlled environment. As such, it is logical to assume that community corrections professionals are likely to favor policies that allow them to exert more control over the offenders they monitor.

\section{CATSO Scale Items}

To date, attitudinal measures included in the CATSO scale (Church et al., 2008) have captured the perceptions and beliefs of three distinct criminal justice populations: parole board members (Tewksbury \& Mustaine, 2011), community corrections professionals (Conley et al., 2011; Tewksbury et al., 2011, in press), and now prison wardens. In terms of views about sex offenders, results suggest significant similarities and minimal differences between criminal justice system actors. Such similarities and differences are noticeable within each of the CATSO scale's four subscales. 
Results from the Social Isolation component reveal that prison wardens, like parole board members and community corrections professionals, do not associate sex offenders with inherent social isolation. Very few believe that sex offenders prefer to stay home alone rather than be around lots of people (18.0\% of wardens, $22.1 \%$ of parole board members, and $18.0 \%$ of community corrections professionals) and feel that sex offenders have difficulty making friends even if they try real hard $(10.3 \%$ of wardens, $9.9 \%$ of parole board members, and $15.7 \%$ of community corrections professionals). Likewise, a large proportion does not believe that most sex offenders keep to themselves ( $80.9 \%$ of wardens, $85.9 \%$ of parole board members, and $84.2 \%$ of community corrections professionals), are unmarried men ( $86.4 \%$ of wardens, $88.8 \%$ of parole board members, and $90.9 \%$ of community corrections professionals), and do not have close friends ( $85.2 \%$ of wardens, $90.3 \%$ of parole board members, and $82.1 \%$ of community corrections professionals).

Results from the Capacity to Change component indicate that prison wardens, like parole board members and community corrections professionals, consider sex offenders to be capable of change. A majority $(67.2 \%$ of wardens, $79.3 \%$ of parole board members, and $77.1 \%$ of community corrections professionals) believes that sex offenders can learn to change their behavior with support and therapy, and only a small proportion (16.2\% of wardens, $8.4 \%$ of parole board members, and $11.8 \%$ of community corrections professionals) feels that trying to rehabilitate a sex offender is a waste of time. Few ( $7.4 \%$ of wardens, $2.8 \%$ of parole board members, and $10.2 \%$ of community corrections professionals) believe that convicted sex offenders should never be released from prison. And yet, more than one-half ( $55.9 \%$ of wardens, $50.7 \%$ of parole board members, and 
$51.0 \%$ of community corrections professionals) feel that sex offenders should wear tracking devices so their location can be pinpointed at any time. However, wardens (40.3\%) are more likely than parole board members (27.5\%) and community corrections professionals (36.1\%) to believe that sex offenders should lose their civil rights.

Results from the Severity/Dangerousness component suggest further similarities between prison wardens, parole board members, and community corrections professionals. Among these criminal justice system actors, sex offenders are generally viewed as serious criminals who are especially dangerous. Nearly all do not consider sex offenders who use emotional control to be less serious than sex offenders who use physical control ( $95.6 \%$ of wardens, $94.4 \%$ of parole board members, and $94.9 \%$ of community corrections professionals), do not perceive sex offenses against known victims to be less serious than sex offenses against strangers $(97.1 \%$ of wardens, $95.9 \%$ of parole board members, and $90.4 \%$ of community corrections professionals), and do not feel that male sex offenders should be punished more severely than female sex offenders ( $94.1 \%$ of wardens, $95.8 \%$ of parole board members, and $97.6 \%$ of community corrections professionals). Similarly, a large majority ( $85.3 \%$ of wardens, $76.4 \%$ of parole board members, and $\mathbf{8 8 . 3 \%}$ of community corrections professionals) does not believe the prison sentences that sex offenders receive are much too long when compared to the sentence durations for other crimes. And, only about one-third ( $27.9 \%$ of wardens, $38.9 \%$ of parole board members, and $32.2 \%$ of community corrections professionals) feel that only a few sex offenders are dangerous.

In addition, similarities arise between prison wardens, parole board members, and community corrections professionals with results from the Deviancy component. These 
criminal justice system actors do not consider sex offenders to be more deviant or sexually preoccupied than other individuals. Few (10.5\% of wardens, $12.9 \%$ of parole board members, and $9.3 \%$ of community corrections professionals) report that they believe sex offenders want to have sex more often than the average person, and only a minority ( $19.4 \%$ of wardens, $15.9 \%$ of parole board members, and $22.6 \%$ of community corrections professionals) feel that sex offenders in fact do have high rates of sexual activity. However, parole board members (47.9\%) are more likely than wardens (25.0\%) and community corrections professionals (19.4\%) to see sexual fondling as less serious than rape.

CATSO Scale as an Efficient Method of Data Reduction

Findings reveal that the CATSO scale is not an efficient method of data reduction for studying the multiple items that make up the attitudes and beliefs of prison wardens. The substance of factors constructed by two separate factor analyses fail to successfully measure wardens' perceptions of sex offenders. This is consistent with prior recent research, which showed that the CATSO scale, as a collection of items, does not assist in understanding the attitudes and beliefs of parole board members (Tewksbury \& Mustaine, 2011) or community corrections professionals (Conley et al., 2011; Tewksbury et al., in press) any better than each item separately. Thus, at this point, the perceptions of criminal justice system actors about sex offenders cannot be effectively captured with the 18-item instrument. This emphasizes the need for the development of a standardized instrument that can be effectively applied to criminal justice populations, but it also encourages future research to consider using data from a different criminal justice system population to examine the efficacy of the CATSO scale. 


\section{Influences on Prison Wardens' Attitudes and Beliefs}

Results from three separate logistic regression analyses indicate that none of the models (i.e., influences on perceived fairness of community notification laws, influences on perceived effectiveness of community notification laws, and influences on perceived sex offender recidivism) provide a statistically significant understanding of the sources for prison wardens' attitudes and beliefs. Thus, factors beyond demographics, experience, and political views captured in this research may be responsible for impacting the perceptions of wardens regarding sex offender policies. This suggests that something inherent in working as a prison warden may drive his or her perceptions about sex offenders. This may include job responsibilities, training, or the culture of the workplace. It is also possible that the small sample size in this study precluded the revelation of significant models.

This differs from parole board members (Tewksbury \& Mustaine, 2011). As parole board members achieved higher levels of education, they were $20 \%$ less likely to believe that sex offender community notification would effectively reduce sex offenses. Likewise, as parole board members reported more children, their likelihood of agreeing that sex offender community notification would effectively reduce sex offenses increased by $32 \%$.

More research should continue to examine the attitudes and beliefs of criminal justice system actors about sex offenders. This will permit a better understanding of their motives and rationale for implementing and enforcing sex offender policies. Specifically, investigations into prison wardens as a criminal justice population should continue. As noted, only two previous studies have attempted to identify the perceptions of wardens, 
and a significant gap in the scholarly literature remains. Future research, particularly with larger sample sizes, may better illustrate wardens' perceptions of sex offenders and sex offender policies. As the views of more criminal justice system actors are considered, a more solid foundation can be established as to whether or not those implementing and enforcing sex offender policies believe them to be effective. If a substantial proportion of these criminal justice system actors perceive such policies as ineffective, renewed consideration and efforts to modify or remove them becomes more promising.

Beyond perceptions of sex offender policies, attitudes and beliefs toward sex offenders held by various criminal justice actors should also continue to be assessed. Those with negative perceptions about sex offenders may intentionally or inadvertently behave with hostility throughout their interactions with these correctional clients. Such confrontational behavior may negatively thwart the relationships between criminal justice system actors and sex offenders. However, if interactions between criminal justice system actors and sex offenders remain free of inherently negative attitudes, especially when such beliefs are based on misconceptions, the opportunity for sex offender rehabilitation is bolstered. Education aimed at criminal justice actors that debunks misconceptions and affirms the value of rehabilitated sex offenders cannot be underestimated.

When sex offenders are perceived positively, or at least accurately, it is more likely that social contacts in the community will extend them opportunities for employment, housing, education, and identity as a community member that are critical to prevent recidivism. Criminal justice system actors, often necessarily made to interact 
with sex offenders, are in a unique position to positively influence sex offenders to become productive community members by adopting more accurate and positive perceptions.

\section{Limitations}

It is recognized that this research has several limitations. The first concern is whether or not the restricted sampling procedure effectively generated a sample reflective of the target population. Again, the target population for this study included all prison wardens from all 50 states responsible for state-operated adult correctional institutions. However, with only 19 statewide correctional jurisdictions selected for inclusion in the present study, whether or not the results are representative of the target population remains to be seen.

Perhaps the most critical limitation is the small sample size $(n=68)$ and associated response rate $(28.3 \%)$. As a result, the generalizability of the findings is questionable. Despite the fact that prison wardens in this study represent each of the 19 randomly selected jurisdictions in the United States, these findings may or may not apply to prison wardens in other jurisdictions.

Because this research relies on self-report data, another limitation is the fact that the truthfulness and accuracy of responses cannot be verified. There may also be dimensions of views about sex offenders that the survey instrument failed to address or specified incorrectly. However, a large portion of the instrument incorporates survey items from prior research (Church et al., 2008; Tewksbury \& Mustaine, 2011), which included various indicators of attitudes and beliefs about sex offenders and sex offender policies. 


\section{Conclusion}

The most valuable aspect of this research is arguably its revelations regarding prison wardens' perceptions of criminal justice policies aimed at sex offenders. Sex offender registration and community notification laws attempt to reduce recidivism and promote community safety by increasing sex offender awareness. Consistent with prior research on the perceptions of the public (Levenson et al., 2007), law enforcement (Redlich, 2001), community corrections professionals (Datz, 2009; Tewksbury et al., 2011), and parole board members (Tewksbury \& Mustaine, 2011), this study shows that a majority of prison wardens believe sex offender registration and community notification are effective in preventing sexual victimization. These attitudes and beliefs hold despite research that has demonstrated that sex offender registration and community notification do not generate significant decreases in sex offenses or increases in public safety (Barnes et al., 2009; Duwe et al., 2008; Tewksbury \& Jennings, 2010; Zgoba et al., 2010)

Residency restriction laws have been created as a result of increasing concern about registered sex offenders living in communities. This study shows that, like members of the general public (Levenson et al., 2007), lawmakers (Sample \& Kadleck, 2008), and community corrections professionals (Tewksbury et al., 2011), a majority of prison wardens believe sex offender residency restrictions are effective in preventing sexual victimization. Again, these groups hold these attitudes and beliefs despite research that has suggested that such restrictions have little or no effect on sex offender recidivism (Blood, Watson, \& Stageberg, 2008; Duwe et al., 2008; Tewksbury, Jennings, \& Zgoba, 2012). This study also shows that schools and daycares are the types of locations most commonly viewed by wardens as appropriate sites from which to prohibit 
sex offenders from living near. And yet, previous research has specifically found no association between residential proximity to school and daycares and sex offender recidivism (Colorado Department of Public Safety, 2004; Minnesota Department of Corrections, 2003, 2007). This sharp contrast between attitudes and beliefs about sex offender policies and scientific evidence, especially among criminal justice actors, should be considered highly alarming.

As managers of correctional institutions, prison wardens occupy important leadership roles in corrections, and they are often uniquely exposed to the long-term presence of sex offenders. Because of this, such actors would be expected to be cognizant of effective management strategies or policies that are designed to monitor sex offenders. It makes sense that awareness of the efficacy of policies inside correctional institutions would translate into recognition of effective sex offender policies in the community. However, this is not the case. It is interesting that wardens generally do not want sex offenders to expose their sex offenses to other inmates, and yet they endorse community notification. This, then, suggests that even among those (prison wardens) who actively monitor and supervise sex offenders within a different context (prison), the inability to form objective views about sex offender policies persists.

More research should examine the rationale for being unable to hold objective views about the effectiveness of sex offender policies among prison wardens and other criminal justice system actors. This research shows that wardens, like parole board members (Tewksbury \& Mustaine, 2011) and community corrections professionals (Conley et al., 2011; Tewksbury et al., in press), consider sex offenders to be capable of change, do not consider sex offenders to be more deviant or sexually preoccupied than 
other individuals, do not consider sex offenders to be loners, and consider sex offenders as serious criminals who are especially dangerous. However, these perceptions, and whether or not they are related to views about sex offender policies, deserve further attention and explanation that cannot be provided by the present study. The qualitative experiences of criminal justice system actors may prove to be useful in determining whether such views on sex offenders influence perceptions of sex offender policies. Ultimately, it may be important to implement education programs aimed at criminal justice system actors that debunk misconceptions about sex offenders and reveal the ineffectiveness of sex offender policies. As it relates to prison wardens, state correctional agencies should mandate participation in such programs on a routine basis. Once this is accomplished, a new, more accurate outlook about sex offenders and sex offender policies may surface within the criminal justice system. This, in turn, may lead to improved opportunities for sex offenders to avoid recidivism and become more productive community members. 


\section{REFERENCES}

Adkins, G., Huff, D., \& Stageberg, P. (2000). The Iowa Sex Offender Registry and recidivism. Des Moines: Iowa Department of Human Rights.

Anderson, A.L., \& Sample, L.L. (2008). Public awareness and action resulting from sex offender community notification laws. Criminal Justice Policy Review, 19(4), 371-396.

Barnes, J.C., Dukes, T., Tewksbury, R., \& De Troye, T. (2009). Predicting the impact of a statewide residence restriction law on South Carolina sex offenders. Criminal Justice Policy Review, 20(1), 21-43.

Beck, V.S., \& Travis, L.F. (2004). Sex offender notification and protective behavior. Violence and Victims, 19(3), 289-302.

Blood, P., Watson, L., \& Stageberg, P. (2008). State legislation monitoring report: FY 2007. Des Moines, IA: Iowa Department of Human Rights: Division of Criminal Justice and Juvenile Justice Planning.

Brannon, Y.N., Levenson, J.S., Fortney, T., \& Baker, J.N. (2007). Attitudes about community notification: A comparison of sexual offenders and the non-offending public. Sexual Abuse: A Journal of Research and Treatment, 19(4), 369-379.

Buckler, K. G., \& Travis, L. F. (2003). Reanalyzing the prevalence and social context of collateral consequence statutes. Journal of Criminal Justice, 31(5), 435-453.

Bumby, K.M., \& Maddox, M.C. (1999). Judges' knowledge about sexual offenders, difficulties presiding over sexual offense cases, and opinions on sentencing, treatment, and legislation. Sexual Abuse: A Journal of Research and Treatment, 11(4), 305-315.

Burchfield, K.B. (2012). Assessing community residents' perceptions of local registered sex offenders: Results from a pilot survey. Deviant Behavior, 33(4), 241-259.

Burton, V. S., Cullen, F. T., \& Travis, L. F. (1987). The collateral consequences of a felony conviction: A national study of state statutes. Federal Probation, 51(3), $52-60$.

Caputo, A.A., \& Brodsky, S.L. (2004). Citizen coping with community notification of released sex offenders. Behavioral Sciences and the Law, 22(2), 239-252. 
Church, W.T., Wakeman, E.E., Miller, S.L., Clements, C.B., \& Sun, F. (2008). The Community Attitudes Toward Sex Offenders Scale: The development of a psychometric assessment instrument. Research on Social Work Practice, 18(3), 251-259.

Colorado Department of Public Safety. (2004). Report on safety issues raised by living arrangements for and location of sex offenders in the community. Denver, Colorado: Author.

Comartin, E.B., Kernsmith, P.D., \& Kernsmith, R.M. (2009). Sanctions for sex offenders: Fear and public policy. Journal of Offender Rehabilitation, 48(7), 605-619.

Conley, T., Hill, K., Church, W.T., Stoeckel, E., \& Allen, H. (2011). Assessing probation and community corrections workers' attitudes toward sex offenders using the Community Attitudes Toward Sex Offenders (CATSO) scale in a rural state. Sexual Addiction and Compulsivity, 18(2), 75-85.

Craun, S.W. (2010). Evaluating awareness of registered sex offenders in the neighborhood. Crime and Delinquency, 56(3), 414-435.

Craun, S.W., Kernsmith, P.D., \& Butler, N.K. (2011). Anything that can be a danger to the public: Desire to extend registries beyond sex offenses. Criminal Justice Policy Review, 22(3), 375-391.

Craun, S.W., \& Theriot, M.T. (2009). Misperceptions of sex offender perpetration: Considering the impact of sex offender registration. Journal of Interpersonal Violence, 24(12), 2057-2072.

Datz, A.L. (2009). Sex offender residency restrictions and other sex offender management strategies: The probation officer perspective in Florida. Tallahassee, FL: Bureau of Probation and Parole Field Services.

Dodge, M., \& Pogrebin, M. R. (2001). Collateral costs of imprisonment for women: Complications of reintegration. The Prison Journal, 81(1), 42-54.

Duwe, G., Donnay, W., \& Tewksbury, R. (2008). Does residential proximity matter? A geographic analysis of sex offense recidivism. Criminal Justice and Behavior, 35(4), 484-504.

Elbogen, E.B., Patry, M., \& Scalora, M.J. (2003). The impact of community notification laws on sex offender treatment attitudes. International Journal of Law and Psychiatry, 26(2), 207-219.

Farkas, M.A., \& Miller, G. (2007). Reentry and reintegration: Challenges faced by families of convicted sex offenders. Federal Sentencing Reporter, 20(2), 88-92. 
Finn, P. (1997). Sex offender community notification. Washington: National Institute of Justice.

Gaines, J.S. (2006). Law enforcement reactions to sex offender registration and community notification. Police Practice and Research, 7(3), 249-267.

Harding, D. (2003). Jean Valjean's dilemma: The management of ex-convict identity in the search for employment. Deviant Behavior, 24(6), 571-596.

Hensley, C., \& Tewksbury, R. (2005a). Wardens' perceptions of prison sex. The Prison Journal, 85(2), 186-197.

Hensley, C., \& Tewksbury, R. (2005b). Wardens' perceptions of inmate fear of sexual assault: A research note. The Prison Journal, 85(2), 198-203.

Hogue, T.E. (1993). Attitudes towards prisoners and sexual offenders. In N.C. Clark \& G. Stephenson (Eds.), DCLP Occasional papers: Sexual offenders (pp. 27-32). Leicester: British Psychological Society.

Kernsmith, P.D., Comartin, E., Craun, S.W., \& Kernsmith, R.M. (2009). The relationship between sex offender registry utilization and awareness. Sexual Abuse: A Journal of Research and Treatment, 21(2), 181-193.

Kernsmith, P.D., Craun, S.W., \& Foster, J. (2009). Public attitudes toward sexual offenders and sex offender registration. Journal of Child Sexual Abuse, 18(3), 290-301.

Lea, S., Auburn, T., \& Kibblewhite, K. (1999). Working with sex offenders: The perceptions and experiences of professionals and paraprofessionals. International Journal of Offender Therapy and Comparative Criminology, 43(1), 103-119.

Levenson, J.S., Brannon, Y.N., Fortney, T., \& Baker, J.N. (2007). Public perceptions about sex offenders and community protection policies. Analyses of Social Issues and Public Policy, 7(1), 137-161.

Levenson, J.S., Zgoba, K.M., \& Tewksbury, R. (2007). Sex offender residence restrictions: Sensible crime policy or flawed logic? Federal Probation, 71(3), 2-9.

Levenson, J.S., \& Cotter, L.P. (2005a). The effect of Megan's Law on sex offender reintegration. Journal of Contemporary Criminal Justice, 21(1), 49-66.

Levenson, J.S., \& Cotter, L.P. (2005b). The impact of sex offender residence restrictions: 1,000 feet from danger or one step from absurd? International Journal of Offender Therapy and Comparative Criminology, 49(2), 168-178. 
Levenson, J.S., Fortney, T., \& Baker, J.N. (2010). Views of sexual abuse professionals about sex offender notification policies. International Journal of Offender Therapy and Comparative Criminology, 54(2), 150-168.

Levenson, J.S., \& Tewksbury, R. (2009). Collateral damage: Family members of registered sex offenders. American Journal of Criminal Justice, 34(1-2), 54-68.

Logan, W.A. (2009). Knowledge as power: Criminal registration and community notification laws in America. Stanford: Stanford University Press.

Mancini, C., Shields, R.T., Mears, D.P., \& Beaver, K.M. (2010). Sex offender residence restriction laws: Parental perceptions and public policy. Journal of Criminal Justice, 38(5), 1022-1030.

Minnesota Department of Corrections. (2003). Level three sex offenders' residential placement issues. St. Paul: Author.

Minnesota Department of Corrections. (2007). Residential proximity and sex offender recidivism in Minnesota. St. Paul: Author.

Olivares, K. M., Burton, V. S., \& Cullen, F. T. (1996). The collateral consequences of a felony conviction: A national study of state legal codes 10 years later. Federal Probation, 60(3), 10-17.

Pogrebin, M. R., Dodge, M., \& Katsampes, P. (2001). The collateral costs of short-term jail incarceration: The long-term social and economic disruptions. Corrections Management Quarterly, 5(4), 64-69.

Quinn, J., Forsyth, C., \& Mullen-Quinn, C. (2004). Societal reaction to sex offenders: A review of the origins and results of the myths surrounding their crimes and treatment amenability. Deviant Behavior, 25(3), 215-233.

Redlich, A.D. (2001). Community notification: Perceptions of its effectiveness in preventing child sexual abuse. Journal of Child Sexual Abuse, 10(3), 91-116.

Robbers, M.L.P. (2009). Lifers on the outside: Sex offenders and disintegrative shaming. International Journal of Offender Therapy and Comparative Criminology, 53(1), $5-28$.

Sample, L.L., \& Kadleck, C. (2011). Sex offender laws: Legislators' accounts of the need for policy. Criminal Justice Policy Review, 19(1), 40-62.

Schiavone, S.K., Jeglic, E.L. (2009). Public perceptions of sex offender social policies and the impact on sex offenders. International Journal of Offender Therapy and Comparative Criminology, 35(6), 679-695. 
Schram, D.D., \& Milloy, C.D. (1995). Community notification: A study of offender characteristics and recidivism. Olympia, WA: Washington Institute for Public Policy.

Tewksbury, R. (2004). Experiences and attitudes of registered female sex offenders. Federal Probation, 68(3), 30-33.

Tewksbury, R. (2005). Collateral consequences of sex offender registration. Journal of Contemporary Criminal Justice, 21(1), 67-81.

Tewksbury, R. (2006). Sex offender registries as a tool for public safety: Views from registered sex offenders. Western Criminology Review, 7(1), 1-8.

Tewksbury, R. (in press). Stigmatization of sex offenders. Deviant Behavior.

Tewksbury, R., \& Higgins, G.E. (2005). What can be learned from an online sex offender registry site? Journal of Community Corrections, 14(3), 9-11, 15-16.

Tewksbury, R., \& Humkey, T. (2010). Prohibiting registered sex offenders from being at school: Assessing the collateral consequences of a public policy. Justice Policy Journal, 7(2). Available at: http://www.cjcj.org/justice_policy_journal.

Tewksbury, R., \& Jennings, W.G. (2010). Assessing the impact of sex offender registration and community notification on sex offending trajectories. Criminal Justice and Behavior, 37(5), 570-582.

Tewksbury, R., Jennings, W.G., \& Zgoba, K.M. (2012). Final report on sex offenders: Recidivism and collateral consequences. Washington: U.S. Department of Justice.

Tewksbury, R., \& Lees, M.B. (2006a). Sex offenders on campus: University-based sex offender registries and collateral consequences of registration. Federal Probation, $70(3), 50-56$.

Tewksbury, R., \& Lees, M.B. (2006b). Perceptions of sex offender registration: Collateral consequences and community experiences. Sociological Spectrum, 26(3), 309-334.

Tewksbury, R., \& Lees, M.B. (2007). Perceptions of punishment: How registered sex offenders view registries. Crime and Delinquency, 53(3), 380-407.

Tewksbury, R., \& Levenson, J.S. (2009). Stress experiences of family members of registered sex offenders. Behavioral Sciences and the Law, 27(4), 611-626.

Tewksbury, R., \& Mustaine, E.E. (2007). Collateral consequences and community reentry for registered sex offenders with child victims: Are the challenges even greater? Journal of Offender Rehabilitation, 46(1-2), 113-131. 
Tewksbury, R., \& Mustaine, E.E. (2011). Parole board members' views of sex offender registration and community notification. American Journal of Criminal Justice. DOI: $10.1007 / \mathrm{s} 12103-011-9119-1$.

Tewksbury, R., Mustaine, E.E., \& Payne, B.K. (2011). Community corrections professionals' views of sex offenders, sex offender registration and community notification, and residency restrictions. Federal Probation, 75(3), 45-50.

Tewksbury, R., Mustaine, E.E., \& Payne, B.K. (in press). Community corrections professionals' attitudes about sex offenders: Is the CATSO applicable? Criminal Justice Studies.

Weekes, J.R., Pelletier, G., \& Beaudette, D. (1995). Correctional officers: How do they perceive sex offenders? International Journal of Offender Therapy and Comparative Criminology, 39(1), 55-61.

Wheelock, D. (2005). Collateral consequences and racial inequality: Felon status restrictions as a system of disadvantage. Journal of Contemporary Criminal Justice, 21(1), 82-90.

Zevitz, R.G. (2006). Sex offender community notification: Its role in recidivism and offender reintegration. Criminal Justice Studies, 19(2), 193-208.

Zevitz, R.G., \& Farkas, M.A. (2000a). Sex offender community notification: Examining the importance of neighborhood meetings. Behavioral Sciences and the Law, 18(2-3), 393-408.

Zevitz, R.G., \& Farkas, M.A. (2000b). Sex offender community notification: Managing high risk criminals or exacting further vengeance? Behavioral Sciences and the Law, 18(2-3), 375-391.

Zgoba, K.M, Witt, P., Dalessandro, M., \& Veysey, B. (2008). Megan's Law: Assessing the practical and monetary efficacy. Washington, DC: National Institute of Justice.

Zgoba, K.M., Veysey, B.M., \& Dalessandro, M. (2010). An analysis of the effectiveness of community notification and registration: Do the best intentions predict the best practices? Justice Quarterly, 27(5), 667-691. 


\title{
CURRICULUM VITAE \\ DAVID PATRICK CONNOR
}

\section{Current Position}

\author{
Graduate Student \\ Department of Justice Administration \\ College of Arts and Sciences \\ University of Louisville \\ Brigman Hall 102E \\ Louisville, KY 40292 \\ 502-852-6086 \\ david.connor@louisville.edu
}

\section{RESEARCH INTERESTS}

- Sex offenders and sex crimes

- Criminal registration and notification

- Collateral consequences of convictions

- Institutional corrections

- Felon disenfranchisement

\section{EDUCATION}

M.S. UNIVERSITY OF LouISVILLE, Administration of Justice

Dr. Richard Tewksbury, Chair

B.A. NORTHERn Kentucky University, Radio/Television

MAY 2009

Summa Cum Laude

Minor in Criminal Justice

\section{Publications}

\section{Journal Articles}

Connor, D.P., Copes, H., \& Tewksbury, R. (2011). Incarcerated sex offenders' perceptions of prison sex offender treatment programs. Justice Policy Journal, 8(2). Available online at http://www.cjcj.org/files/Incarcerated_Sex.pdf 
Connor, D.P., \& Tewksbury, R. (2012). Social control on public buses. Journal of Theoretical and Philosophical Criminology, 4(1), 1-13. Available online at http://www.jtpcrim.org/January_2012/Social-Control-on-Public-Buses.pdf

Connor, D.P., \& Tewksbury, R. (in press). Ex-offenders and educational equal access: Doctoral programs in criminology and criminal justice. Critical Criminology. DOI: $10.1007 / \mathrm{s} 10612-011-9142-\mathrm{z}$

\section{Book Chapters}

Tewksbury, R., Holmes, R.M., \& Connor, D.P. (in press). Typologies of teenage suicide: Analyzing suicide notes through Durkheimian categories. In T. Calhoun, A. Thio, \& A. Conyers (Eds.), Deviance Today.

Tewksbury, R., \& Connor, D.P. (in press). Inmate reentry. In D. McDonald \& A. Miller (Eds.), Race, Gender, and Criminal Justice: Equality and Justice for All? San Diego, CA: Cognella Academic Publishing.

\section{Book Reviews}

Connor, D.P. (2011). Book review: Explaining U.S. imprisonment. Criminal Justice Review, 36(4), 519-521.

\section{Technical Reports}

Tewksbury, R., \& Connor, D.P. (2011). Needs of sex offenders approaching release: Report prepared for the Kentucky State Reformatory.

\section{Encyclopedia Articles}

Tewksbury, R., \& Connor, D.P. (in press). Laws and criminal justice policies regarding sex offenders. In G. Bruinsma \& D. Weisburg (Eds.), Encyclopedia of Criminology and Criminal Justice.

\section{Presentations}

Connor, D.P., \& Tewksbury, R. (February 2012). Incarcerated sex offenders' perceptions of family relationships: Previous experiences and future expectations. Paper presented at the annual meeting of the American Association of Behavioral and Social Sciences, Las Vegas, NV.

Connor, D.P., \& Tewksbury, R. (November 2011). Ex-offenders and educational equal access: Doctoral programs in criminology and criminal justice. Paper presented at the annual meeting of the American Society of Criminology, Washington, DC. 
Connor, D.P., Copes, H., \& Tewksbury, R. (September 2011). Incarcerated sex offenders' perceptions of prison sex offender treatment programs. Paper presented at the annual meeting of the Southern Criminal Justice Association, Nashville, TN.

Connor, D.P. (April 2011). Incarcerated sex offenders' perceptions of prison sex offender treatment programs. Poster session presented at the Third Annual Graduate Research Symposium, University of Louisville, Louisville, KY.

\section{HONORS AND AWARDS}

Graduate Assistantship Appointment

Department of Justice Administration

UNIVERSITY OF LOUISVILLE, Louisville, KY

Top Scholar Award

SPRING 2009

Department of Communication

NORTHERN KENTUCKY UNIVERSITY, Highland Heights, KY

\section{RESEARCH EXPERIENCE}

Graduate Research Assistant

2010 - PRESENT

Department of Justice Administration

UNIVERSITY OF LOUISVILLE, Louisville, KY

TEACHING EXPERIENCE

Graduate Teaching Assistant

SUMMER 2011

Department of Justice Administration

UNIVERSITY OF LOUISVILLE, Louisville, KY

- JA 326-Quantitative Analysis

Teaching Assistant

SPRING 2009

Office of First-Year Programs

NORTHERN KENTUCKY UNIVERSITY, Highland Heights, KY

- UNV 101 - Orientation to College and Beyond

\section{Professional Affiliations}

American Association of Behavioral and Social Sciences

American Society of Criminology

2009 - PRESENT

Southern Criminal Justice Association

2011 - PRESENT

Alpha Phi Sigma Criminal Justice Honor Society

2011 - PRESENT 